Portland State University

PDXScholar

4-13-1976

\title{
Structural Geology of the Northeast Quarter of the Dutchman Butte Quadrangle, Southwest Oregon
}

\author{
Rauno K. Perttu \\ Portland State University
}

Follow this and additional works at: https://pdxscholar.library.pdx.edu/open_access_etds

Part of the Geology Commons

Let us know how access to this document benefits you.

\section{Recommended Citation}

Perttu, Rauno K., "Structural Geology of the Northeast Quarter of the Dutchman Butte Quadrangle, Southwest Oregon" (1976). Dissertations and Theses. Paper 2442.

https://doi.org/10.15760/etd.2439

This Thesis is brought to you for free and open access. It has been accepted for inclusion in Dissertations and Theses by an authorized administrator of PDXScholar. Please contact us if we can make this document more accessible: pdxscholar@pdx.edu. 
AN ABSTRACT OF THE THESIS OF Rauno Perttu for the Master of Science in Geology presented June 1976.

Title: Structural Geology of the Northeast Quarter of the Dutchman Butte Quadrangle, Southwest Oregon.

APPROVED BY MEMBERS OF THE THESIS COMMITTEE:

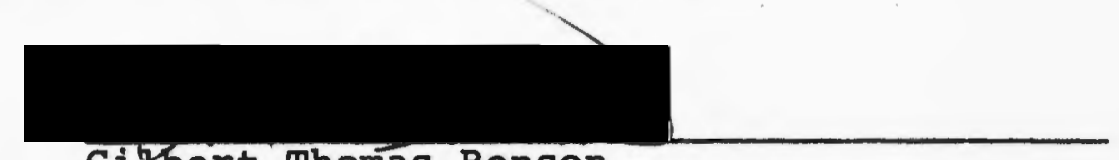

Gilbert Thomas Benson

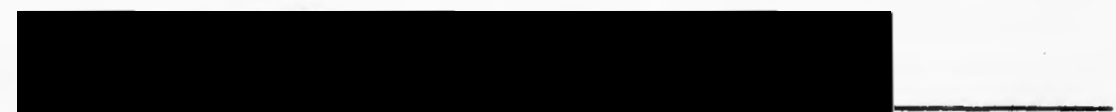

Ewart M. Baldwin

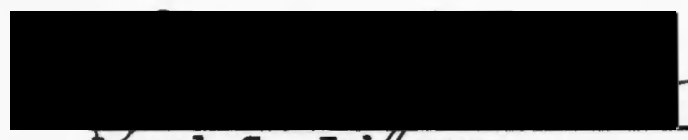

Anse1 G. Jolhson.

The northeast quarter of the Dutchman Butte quadrangle straddles the boundary of the Mesozoic Klamath Mountains province and the Tertiary Coast Range province. The boundary in this area is controlled by a major easttrending fault zone, hẹein named the Canyonville fault zone. Jurassic Rogue, Dothan, and Otter Point Formations have been offset right-laterally at least 40 kilometers. In latest Jurassic and early Cretaceous time, the fault zone formed the shoreline along which sediments of the Myrtle Group were deposited. 
Movement on the Canyonville fault zone became down-to-the-north in Eocene time forming the southern margin of the Eocene Coast Range basin. Rocks of the lower to middle Eocene Roseburg and Lookingglass Formations thin and pinch-out, and become shallow marine to nonmarine in character southward across the fault zone. Fault movement decreased in Lookingglass time, and essentially ceased by Tyee (middle Eocene) time.

Eocene structures in the thesis area formed contemporaneously with sedimentation; individual structures controlled and were controlled by the stratigraphy of the Eocene units. 
STRUCTURAI GEOLOGY OF THE NORTHEAST QUARTER OF THE DUTCHMAN BUTTE QUADRANGLE, SOUTHWEST OREGON

by

RAUNO K. PERTTU

A thesis submitted in partial fulfillment of the requirements for the degree of

MASTER OF SCIENCE

in

GEOLOGY

Portland State University

1976 
TO THE OFFICE OF GRADUATE STUDIES AND RESEARCH:

The members of the Committee approve the thesis of Rauno K. Perttu presented April 13, 1976.

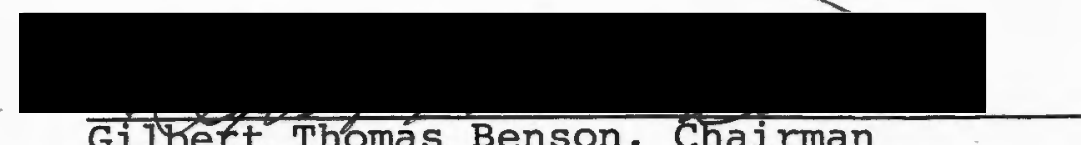

Gilbert Thomás Benson, Chairman

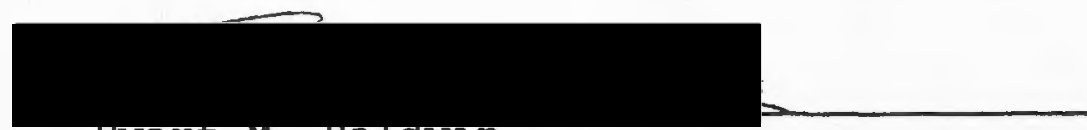

Ewart M. Balawin

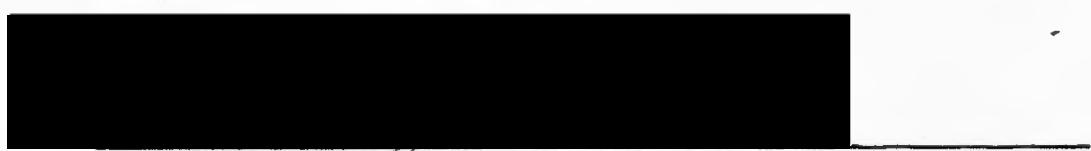

Ansel G. Joh́nson

APPROVED:

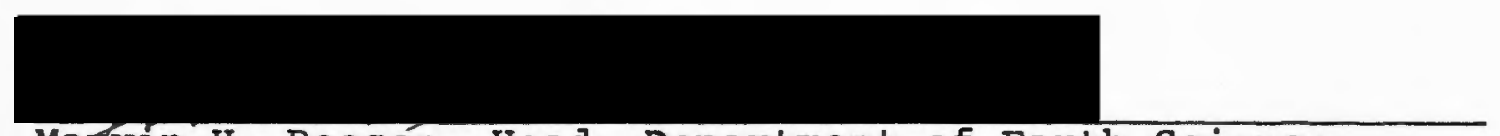

Marvin H. Beesón, Head, Department of Earth Science

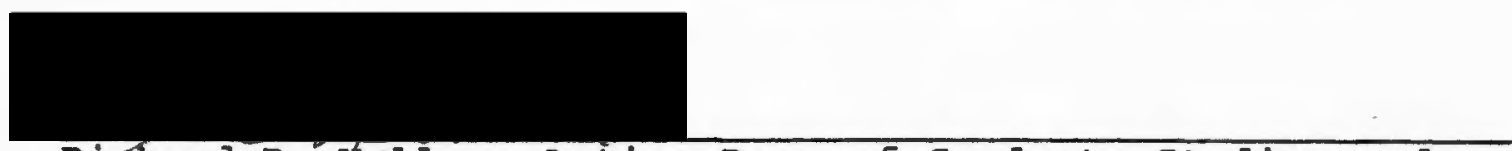

Richard B. Halley, Acting Dean of Graduate Studies and Research 
TABLE OF CONTENTS

PAGE

ACKNOWLEDGMENTS • • • • • • • . . . • • • . v

LIST OF FIGURES . . . . . . . . . . . . . . . vi vi

INTRODUCTION • • . . . . . . . . . . . 1

Purpose of Study . . . . . . . . . . 1

Climate and Land Use . . . . . . . . . 1

GeomorphologY . . . . . . . . . 3

Field Work ............... 3

Previous Work . . . . . . . . . 4

Geologic Setting . . . . . . . . . 4

STRATIGRAPHY . . . . . . . . . . . . 7

Dothan Formation . . . . . . . . 7

Myrtle Group .. . . . . . . . . . . 12

Eocene Formations . . . . . . . . . 18

Units Within the Canyonville Fault zone . . 30

STRUCTURAL GEOLOGY . . . . . . . . . . . 34

Pre-Tertiary Regional Structure . . . . 35

Canyonville Fault Zone . . . . . . . 37

Lookingglass Structure . . . . . . . 39 
PAGE

GEOLOGIC HISTORY

Regional History .... . . . . . . . 48

Local History . . . . . . . . . . . 52

Possible origin of Canyonville zone . . . . . 56

SELECTED REFERENCES . . . . . . . . . . . 58 


\section{ACKNOWLEDGEMENTS}

I would like to thank my advisor, Dr. Gilbert.T. Benson, and Dr. Ewart M: Baldwin for their assistance in the completion of this thesis and for the time they spent with me in my thesis area. I also would like to thank Dr. Ansel Johnson for serving on my committee and for his assistance and critical reading of the manuscript. I thank everyone who supported and helped me in my work or criticized the manuscript. 


\section{LIST OF FIGURES}

FIGURE

PAGE

1. Geologic map. . . . . . . . . . . . pocket

2. Geologic sections. . : . . . . . . . pocket

3. Location map of thesis area. . . . . . . 2

4. Deformed sandstone and siltstone of the

Dothan Formation. Picture was taken

in quarry southeast of Big Dutchman

Butte. •. . . . . . . . . . 8

5. Channel deposited Lookingglass Formation

sandstone resting unconformably on

irregular erosional surface of Dothan

Formation (southeast of Big Dutchman

Butte) . . . . . . . . . . . 13

6. Conglomerate and mudstone of the Riddle

Formation in roadcut east of Buck

Mountain. . . . . . . . . . . 13

7. Minor coal lenses in finer interbed of

Bushnell Rock Member conglomerate in

section 11, T31S, R8W. . . . . . . 24

8. Sandstone channel in roadcut northeast of

Big Dutchman Butte. . . . . . . . 26 
FIGURE

PAGE

9. Dr. Baldwin stands next to a soft-sediment slump feature in Tenmile Member north of Horse Prairie, central thesis area. Such features are common throughout the Tenmile Member. . . . . . . . 26

10. Pebble and sandstone lenses showing channel scour and fill in Olalla Creek Member. Outcrop is in northwest corner of map area. . . . . . . . . . 28

11. Regional geologic setting and possible correlations across Canyonville fault zone. Key to generalized geology: 1) Dothan Formation; 2) "Western" Rogue Formation; 3) Myrtle Group; 4) Serpentine, peridotite belt; 5) Otter Point Formation. $\mathrm{B}=$ Bardon; $\mathrm{C}=$ Canyonville; $\mathrm{CB}=$ Coos Bay; $\mathrm{DC}=$ Days Creek; Ri = Riddle; $\mathbf{R}=$ Roseburg. . . . . . . . . 36

12. East-trending normal fault north of Big Dutchman Butte juxtaposes Olalla Creek Member conglomerate on right against finer grained Tenmile beds on left . . 40

13. Schematic of geologic history of the Canyonville fault zone. . . . . . 49-50 


\section{INTRODUCTION}

The study area is located in Douglas County, west of Riddle, Oregon (Fig. 3). Access is by paved roads along Cow Creek and Union Creek and along numerous unpaved Bureau of Land Management and logging roads.

\section{PURPOSE OF STUDY}

The nature of the boundary between the Klamath Mountains and Coast Range provinces is the principal subject of this thesis. In addition, the stratigraphy of the Coast Range sedimentary units is profoundly affected where they lap southward across the Canyonville fault zone and onto the Klamath Mountain rocks. After preliminary investigation along the boundary, the thesis area was chosen as a critical area to be mapped for a better understanding of the character of the boundary.

\section{CLIMATE AND LAND USE}

Warm dry summers and mild wet winters typify the climate of the area. Temperatures average about 20 degrees centigrade in July and 5 degrees centigrade in January at lower elevations. Annual precipitation 


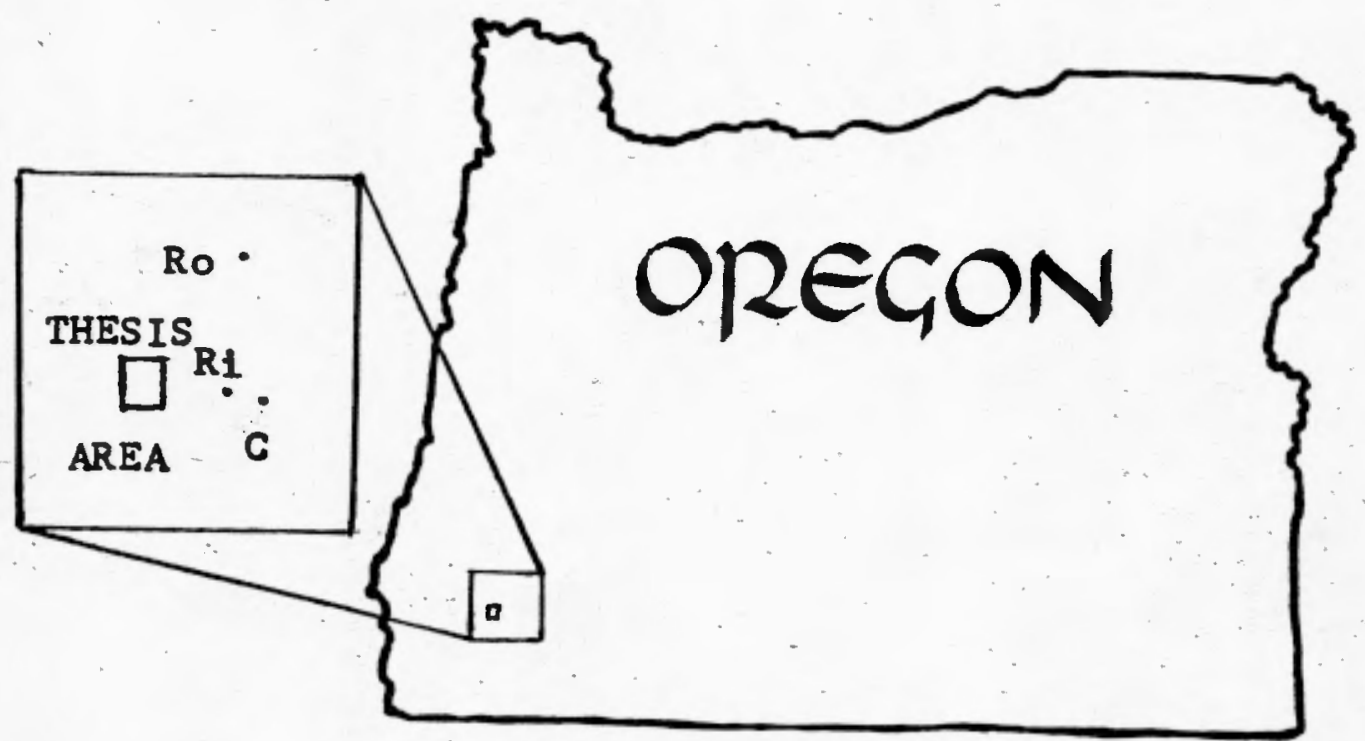

Figure 3. Location Map of Thesis Area. 
over the area averages 75 to 125 centimeters (Dicken, 1955). Snow can persist in the winter months on the higher peaks.

The heavily forested study area is being extensively logged. The clearcut area has grown substantially during the past four years. One small farm along Cow Creek represents the habitation of the area as well as the only agricultural use of the land.

\section{GEOMORPHOLOGY}

The topography of the area is rugged, with 600 to 1000 meters of relief and typically steep slopes. It has been attributed to deep dissection of an uplifted erosional surface (Diller, 1902; Dicken, 1955). The courses of the entrenched meandering streams of Cow Creek and other major drainages of the region have been substantially modified by the structure and lithology of the rocks into which they have cut.

\section{FIELD WORK}

Field study was conducted sporadically during the period 1972 to 1975, for a total of approximately forty days in the field. The base map is the $1: 62,500$ U.S.G.S. Dutchman Butte topographic quadrangle enlarged to $1: 31,250$. Structural analysis, interpretation of 
1:12,000 aerial photographs, and examination of a number of thin sections were also made.

\section{PREVIOUS WORK}

Preliminary regional geological mapping was done by Diller (1898), Diller and Kay (1924), and by Wells and Peck (1961). An unfinished geologic map of the Dutchman Butte quadrangle by Hollis Dole is on file at the Oregon State Department of Mineral Industries offices in Portland and Grants Pass. Ramp (1972) included the area in his geologic map of Douglas County. Baldwin has conducted numerous geologic investigations in the region (e.g. 1965, 1974). Peterson (1957) and Harms (1957) mapped the southeastern third of the Camas valley quadrangle immediately north of the thesis area. Cornell (1971) mapped the northwest quarter of the Canyonville quadrangle immediately to the east. Gerald Black of Portland State University is mapping the adjacent southeast quarter of the Dutchman Butte quadrangle.

\section{GEOLOGIC SETTING}

The thesis area straddles the boundary between the Klamath Mountains and Coast Range geologic provinces. The provinces in this area are separated by an important and complex fault zone, herein named the Canyonville fault zone. 
The Klamath Mountains Province primarily consists of complexly deformed and variably metamorphosed pre-Tertiary sedimentary and igneous rocks. In and near the thesis area, the Klamath Mountains rocks include the Late Jurassic Rogue, Galice, Dothan, and Otter Point Formations, and the Late Jurassic to Early Cretaceous Riddle and Days Creek Formations. In addition to these formations, various exotic rocks are found in the fault zone.

The thesis area includes all of the formations mentioned above, except the Galice. Greenstone metavolcanic units in the Canyonville fault zone (Fig. I) are tentatively assigned to the Rogue Formation, and sedimentary and volcanic rocks in the northern part of the zone are almost certainly slices of the Otter Point Formation. These pre-Tertiary units were deformed near an actively underthrust continental margin (e.g. Coleman, 1971, 1972). Deformation continued into early Eocene time (Perttu and Benson, 1975).

The Coast Range Province lies north of the Klamath Mountains Province. This province includes sedimentary rocks formed in marine, shore zone, and coastal plain environments and basaltic volcanics predominantly of Eocene age near the Klamath Mountains (Baldwin, 1964, 1974). The Coast Range rocks show considerably less deformation than those of the Klamath Mountains, 
with deformation decreasing upward through the lower and middle Eocene section. In sequence, the Coast Range formations in and near the thesis area include the Roseburg, Lookingglass, Fluornoy, and Tyee Formations. of these, only the Roseburg and Lookingglass Formations are mapped in the northeast quarter of the Dutchman Butte quadrangle; the Fluornoy and Tyee Formations crop out north and west of the thesis area. 


\section{STRATIGRAPHY}

\section{DOTHAN FORMATION}

Units assigned to the Dothan Formation (Jd) underlie most of the southern part of the thesis area. The Dothan Formation was named by Diller in 1907 for a nowabandoned railroad station a few kilometers to the southwest along Cow Creek. The Dothan Formation has been mapped from northern California to Róseburg (Dott, 1971; Wells and Peck, 1961). Based on meager fossil evidence, the Dothan is considered Late Jurassic in age (Koch, 1966). Thus, it is thought to be equivalent to the otter Point Formation which crops out north of the map area (Ramp, 1972) and probably within the Canyonville fault zone shown on the map.

The Dothan in the thesis area consists of severely folded, sheared, faulted and commonly veined sandstone, siltstone, and mudstone (Fig. 4), with very minor amounts of chert and breccia, which occur mainly near the northern boundary. Greenstone basic volcanic rocks and conglomerate have been mapped in the Dothan Formation elsewhere. Immediately to the south of the study area, 


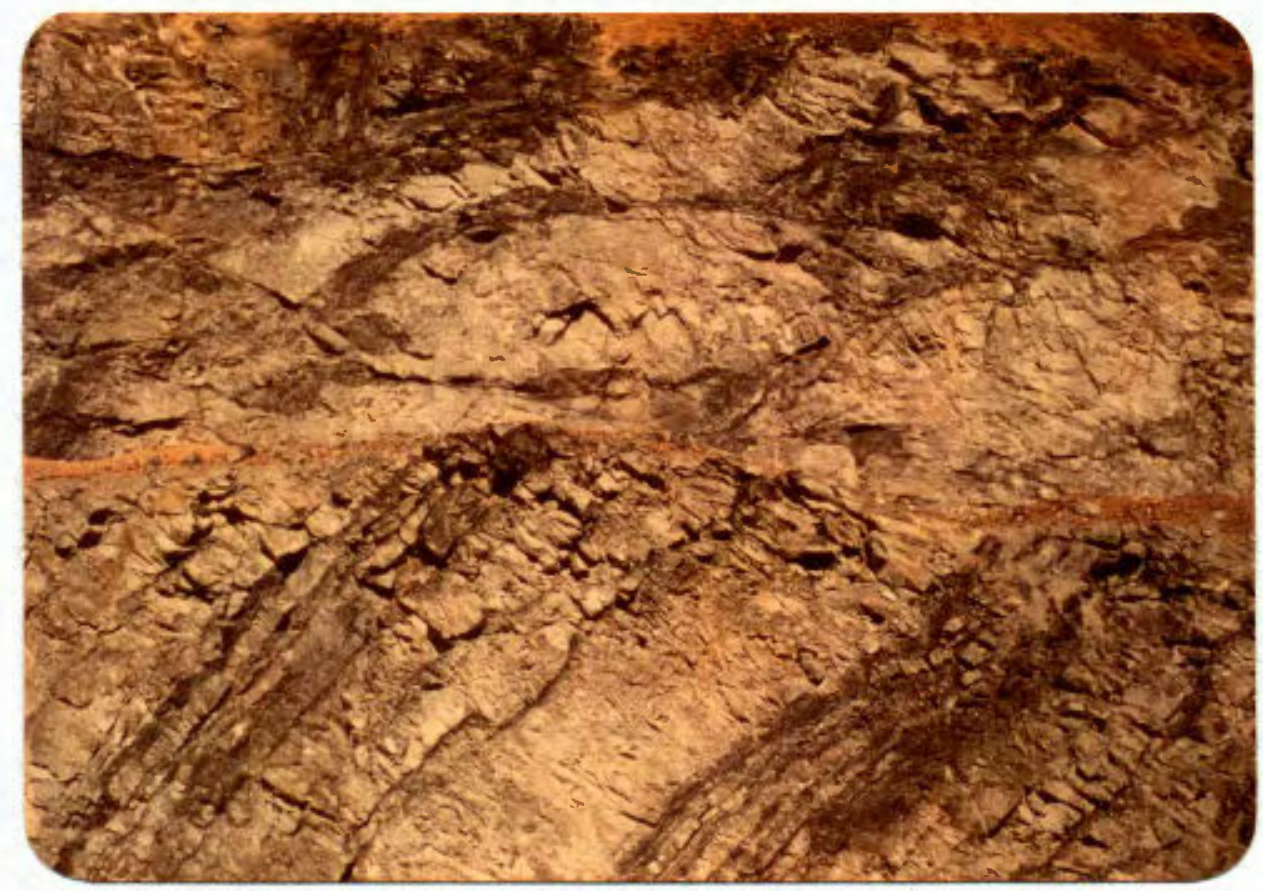

Figure 4. Deformed sandstone and siltstone of the Dothan Formation. Picture was taken in quarry southeast of Big Dutchman Butte. 
in the southeast quarter of the Dutchman Butte quadrangle, Gerald Black (personal communication, 1974) has mapped igneous lenses, conglomerate, and chert in the Dothan Formation:- Cornel1-(1971) found similar units in the Dothan Formation immediately to the east, in the northwest corner of the Canyonville Quadrangle.

Others (e.g. Diller and Kay, 1924; Wells and Peck, 1961; Cornell, 1971) included in the Dothan Formation many of the units in and north of the Canyonville fault zone which crosses the area of the study. In this study no units in or north of the Canyonville fault zone are assigned to the Dothan Formation. Based on lithology, the rocks in and north of the zone which have been included in the Dothan Formation are here assigned to the Otter Point Formation (Coleman and Lamphere, 1971; Ramp, 1972). The volcanic and sedimentary sequence including chert lenses in the Canyonville zone may be partially an ophiolite sequence as postulated by Cornell (197I). If so, they may be associated with the otter Point Formation trench or near-trench deposits. Some sedimentary slices in the zone possibly have been derived from Dothan terrains, but of lithology unlike the Dothan Formation in the southern part of the map area. For example, some of the outcrops resemble unit one of the Dothan Formation described by Kent (1972) in the southeast 
quarter of the Bone Mountain quadrangle to the west, and by Black (personal communication, 1974) in the southern part of the Dutchman Butte quadrangle. The Dothan-like rocks in the Canyonville fault zone also resemble Otter Point Formation sedimentary rocks and may be transitional between the two formations.

Because of deformation, a columnar section of the Dothan would be difficult to construct and would be of dubious value. For the same reason, the thickness of the formation would at best be difficult to determine. A thickness of 6000 meters (Wells and Peck, 1961) may be used as a very rough estimate, although this figure may be high for the map area.

The northeast trending strike of the Dothan beds in the thesis area is similar to the regional trend of the formation, generally $\mathrm{N} 40-50^{\circ} \mathrm{E}$. The beds are steeply dipping and discontinuous because of internal faulting and shearing.

\section{Dothan Sandstone}

In the map area, sandstone makes up considerably more than half of the Dothan Formation. The sandstone beds range in thickness from a few centimeters to a few meters. Because of the intensity of shearing and deformation, individual beds can be followed only a few meters in an outcrop, and then commonly only with 
difficulty. The sandstone, grey to olive on fresh surfaces, is lithic wacke. Iithic fragments are predominantly volcanic. Sericite patches are notable throughout the sandstone, and veining is common. Chert lenses occur rarely in the sandstone, and conglomerate beds are absent in the thesis area, although they have been described in adjacent areas (e.g. Black, personal communication, 1974). Minor local breccia occurs associated with the sandstone near the northern margin of the formation along Union Creek; it may be of tectonic origin. Toward the northern boundary of the Dothan Formation, the amount of sandstone beds appears to decrease somewhat, with a corresponding increase in siltstone and mudstone interbeds.

\section{Dothan Mudstone}

Siltstone and mudstone range from thin interbeds between sandstone beds to thick sections with minor sandstone interbeds. The latter appear to be more common toward the northern boundary. The mudstone and siltstone are locally veined, grey or slightly olive to almost black in fresh exposures. Textures range from massive or slatey to phyllitic. The darker phyllitic types generally occur along fault or shear zones. 
Contact Relationships

The base of the Dothan Formation has not been observed with certainty anywhere. In the study area, the Dothan Formation is in fault contact with rocks of the Canyonville fault zone. A channel-deposited, possibly fluvial facies of the Lookingglass Formation overlies with angular unconformity the Dothan Formation at Big Dutchman Butte. The contact is exposed along a road east of Big Dutchman Butte (Fig. 5). Figure 5 shows the irregular contact between the underlying Dothan Formation. and the basal Lookingglass channel-deposited sandstone.

MYRTLE GROUP

Units of the Myrtle Group, the Riddle (Jr) and Days Creek (Kd) Formations, are found in the thesis area. The Days Creek Formation is represented only by one small outcrop in the northeast corner of the map area. The Myrtle Group was named by Diller (1898) and redefined by Imlay and others (1959). The Riddle and Days Creek Formations, respectively uppermost Jurassic and Lower Cretaceous, are shallow marine and possibly partially nonmarine deposits which unconformably overlie older units in the Canyonville fault zone to the north. No Myrtle Group rocks are found south of the Canyonville fault zone in or near the thesis area. 


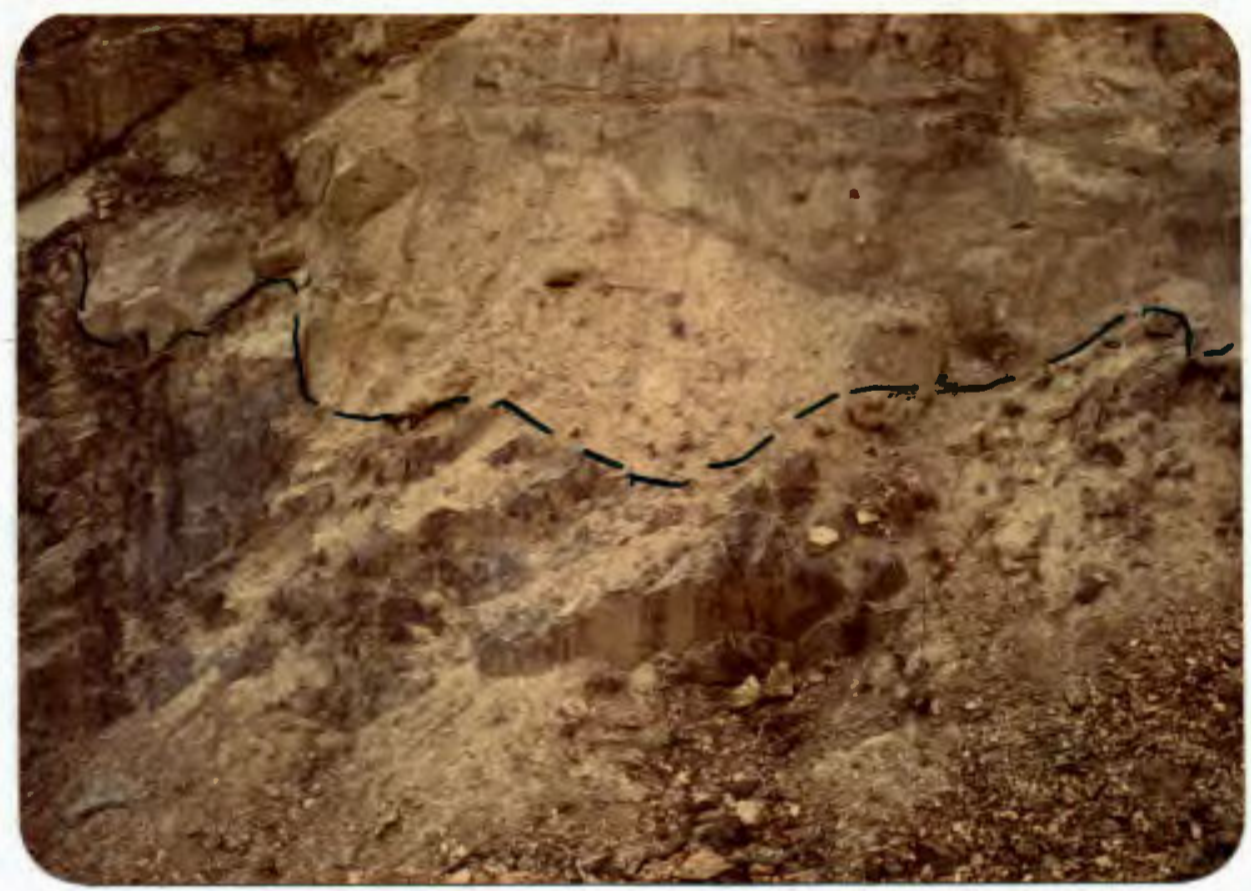

Figure 5. Channel deposited Lookingglass Formation sandstone resting unconformably on irregular erosional surface of Dothan Formation (southeast of Big Dutchman Butte).

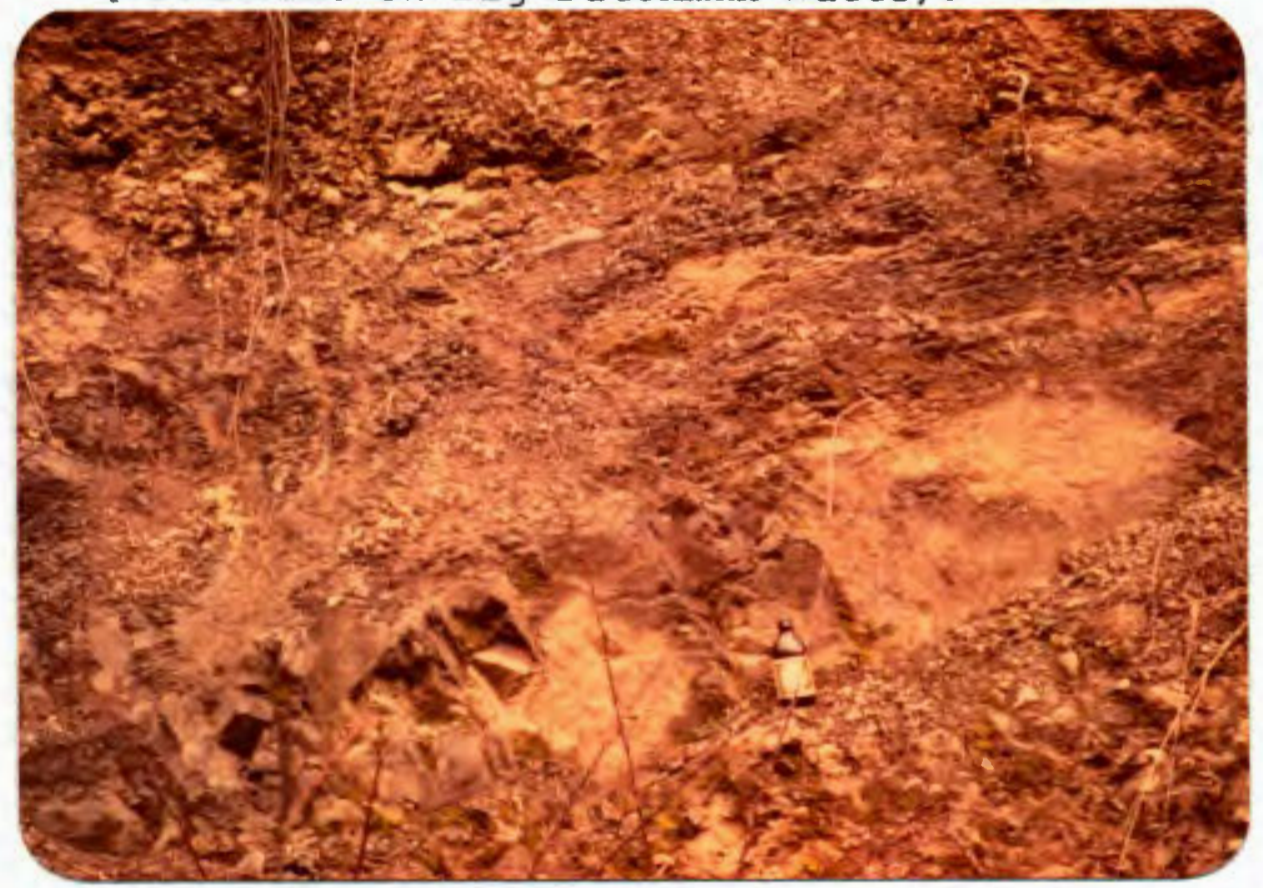

Figure 6. Conglomerate and mudstone of the Riddle Formation in roadcut east of Buck Mountain. 
Riddle Formation

The Riddle Formation (Imlay et al., 1959) occurs in tectonic slices along the southern part of the Canyonville zone and in a large exposure in the northeastern part of the map area. The Riddle Formation consists of conglomerate, sandstone, siltstone, and mudstone, as typified by Figure 6 . In the slice exposed at Cow Creek and Iron Mountain, the formation consists of a thick conglomerate apparently overlain by interbedded mudstone, siltstone, sandstone, and minor pebble beds. Elsewhere, the internal stratigraphy is not clear, although conglomerate is generally dominant. The Riddle Formation is not as deformed or indurated as the Dothan Formation, but internal shearing and faulting obscure the thickness and stratigraphic relationships. No attempt was made to fit the Riddle Formation in the thesis area into the stratigraphic sequence described by Imlay and others (1959) to the east. Even if some of the type section could be distinguished, lateral changes over the intervening distance would make direct correlation questionable.

\section{Riddle Conglomerate}

Good exposures of conglomerate of the Riddle Formation occur at three localities on the thesis map 
(Fig. 1): (1) in sections 2 and 3, T31S, R8W, in the southwest corner of the map area; (2) along the southeastern part of the elongate slice at Iron Mountain; and (3) the large area of conglomerate at Buck Mountain. Bedding is obscure, partly because of deformation, but close inspection of several outcrops suggested that the conglomerate filled channels a few meters to possibly 20 meters wide and a few meters to perhaps 10 meters deep. The conglomerate is generally dark grey to greenish in outcrop with rust colored stains along shear zones and fractures. Clasts range in diameter from less than onehalf centimeter to more than 7.5 centimeters. The majority of beds contain pebbles three centimeters or less in diameter, and the pebbles are usually well rounded to rounded. Black, green, red, and grey chert make up about 80 percent of the pebbles. The non-chert pebbles are of volcanic, sedimentary or very low grade meta-sedimentary origin. Matrix generally accounts for less than 20 percent and locally less than 10 percent of the volume of the conglomerate and is typically composed of sand-sized material and silica. Silica usually fills most of the conglomerate pore space.

In some outcrops, especially near Buck Mountain, the conglomerate is more variable in size, rounding, composition of pebbles, and amount of matrix. Locally, angular 
to well-rounded cobbles to 15 centimeters diameter are found, and mud to sand sized matrix forms more than one third of some beds. Some of these conglomerate beds contain considerably more lithic fragments than typical Riddle conglomerate. The Riddle Formation near Buck Mountain also contains a few coal fragments. Finer grained interbeds locally form over half of the volume of some outcrops.

\section{Finer Grained Riddle Formation}

Sandstone, siltstone, and mudstone are locally interbedded with the conglomerate, especially southeast of Buck Mountain. In addition, three areas of the Riddle Formation contain no significant conglomerates and only local pebble lenses. In two of these areas, southwest of the possible northwest trending fault near Buck Rock and in the west end of the slice which passes through Iron Mountain, bedding is largely obscured; outcrops superficially look like weathered Dothan or otter Point, but are not as indurated or deformed. In these three areas, the Riddle sandstone and siltstone are dominant and appear to have the same general composition as coarser phases. In the third area, on the east side of Cow Creek north of Iron Mountain, pebble conglomerate, sandstone, siltstone and mudstone beds contain Buchia. Fossils from finer interbeds in the conglomerate at Buck Mountain were 
identified by D. C. Jones of the U. S. Geological

Survey as latest Jurassic to very early Cretaceous in age (Jones to Baldwin, personal communication, 1974).

Contact Relationships

The basal contact of the Riddle Formation is exposed during low water along Cow Creek near Iron Mountain, and in an outcrop near upper Union Creek near the center of section 3, T31S, R8W. In both localities, the Riddle conglomerate rests on underlying serpentine. Along Cow Creek a few cobbles possibly derived from the underlying serpentine belt were found in the base of the Riddle Formation. While cold intrusion or fault emplacement of serpentine against the Riddle has taken place, at least along Cow Creek, the Riddle may also depositionally overlie serpentine. Near Union Creek, the contact of the Riddle Formation and underlying serpentine may be depositional, but post-Riddle deformation and small-scale diapirism in the outcrop have obscured the relationships.

The basal conglomerate of the Lookingglass Formation unconformably overlies the Riddle Formation. The unconformable relationships is best shown along the escarpment from Table Mountain to Buck Mountain in the eastern part of the map area. 
Days Creek Formation

A small patch of Days Creek Formation extends into the extreme northeastern corner of the thesis area (Fig. 1), from Cornell's (1971) map. The extension is based on photo interpretation, but the locality was not examined on the ground.

\section{EOCENE FORMATIONS}

Roseburg Formation

Baldwin (1974) has divided Diller's (1898) Umpqua Formation into the early Eocene Roseburg Formation (Ter) (Lower Umpqua), the early to middle Eocene Lookingglass Formation ( $\mathrm{Tel}$ ) (Middle Umpqua), and the middle Eocene Fluornoy Formation (Tef) (Upper Umpqua). Local mudstone, siltstone, and pebbly sandstone beds which overlie the pre-Tertiary rocks and underlie the basal Lookingglass Formation in the thesis area are assigned to the Roseburg Formation. As no definitive fossils were found in these exposures and most of these rocks are somewhat different from the Roseburg to the north, stratigraphic position is the basis of this assignment. Deformation varies from minor to considerable; but at least part of the deformation is caused by recent landsliding. Local soft sediment slump features are also visible in some exposures. 
The best exposure of the Roseburg Formation is in section 34 in the southwest part of the map area. Here, the basal conglomerate of the Lookingglass Formation is underlain by folded and broken mudstone, siltstone, and locally very pebbly sandstone beds. Most of the exposures appear to have been disturbed by recent landsliding. The rocks are probably shallow water, near-shore deposits, which are generally grey to olive and rather thinly bedded. The pebble beds include clasts of varied origin. The sandstone, which varies considerably in coarseness and volume, is wacke with considerable matrix. Some beds are channel deposits. Leaf and other plant fossils are locally evident. Along Table Creek and east of Table Mountain, a few very minor coal lenses are present in Roseburg Formation beds. The Roseburg beds are roughly parallel to the basal Lookingglass conglomerate, and the sediments appear to be of similar facies to the lower energy parts of the Lookingglass Formation.

\section{Contact Relationships}

Although the base of the Roseburg Formation is not clearly exposed, close association with the overlying basal Lookingglass conglomerate suggests that, like the Lookingglass, the Roseburg beds unconformably overlie the older units in the Canyonville fault zone. No basal 
volcanics, which are found under the Roseburg sediments to the north, were observed. Stratigraphic position and facies relationships suggest that the Roseburg of the thesis area is a lower energy local precursor of the basal Lookingglass (Bushnell Rock Member, Baldwin, 1974) cycle of deposition. A corollary would be that while the basal conglomerate of the Lookingglass Formation overlies the Roseburg beds with probable unconformity, in this area the unconformity is not major.

\section{Lookingglass Formation}

The Lookingglass Formation is the most extensively exposed formation in the map area. It was named by Baldwin (Baldwin and Beaulieu, 1973) for the section in Lookingglass Valley to the north of the map area, and subdivided by him (1974) into three members. These members, all present in the Dutchman Butte quadrangle, include a basal conglomerate -- the Bushnell Rock Member ( $\mathrm{Telb})$, an overlying sandstone and/or mudstone unit -- the Tenmile Member (Telt), and an upper, locally conglomeritic, sandstone unit -- the Olalla Creek Member (Telo).

Bushnell Rock Member. The basal conglomerate of the Lookingglass Formation crops out extensively along most of the southern and eastern boundaries of the Tertiary section of the map area. The conglomerate forms 
a continuous north-trending ridge along the eastern boundary of the formation in the map area, an extensive southern dip slope of Table Mountain, and large exposures in the southwestern part of the map area. The basal conglomerate does not extend south of the Canyonville fault zone. Instead, at Big Dutchman Butte, the basal conglomerate is replaced by a different facies including locally pebbly channel sandstone, siltstone, and mudstone beds of possibly fluvial origin. The Big Dutchman Butte section may be the equivalent of both the Bushnell Rock Member and the overlying Tenmile Member. Alternatively, the basal conglomerate may truncate along the easttrending fault zone north of the butte (see Fig. 1).

In most of the thesis area, Bushnell Rock Member conglomerate unconformably overlies all of the units of the map area with the probable exception of the Dothan Formation. The conglomerate varies in thickness from little more than 20 meters to over 300 meters. At Table Mountain, the apparently very thick exposure of the Bushnell Rock Member is on a southerly dip slope which has been eroded to the resistant conglomerate. Minor faulting has also extended this area of exposure, increasing the apparent thickness.

Bedding is poorly developed in the Bushnell Rock Member, although lens-shaped (channel) beds are apparent. Individual beds are usually less than 3 meters 
thick, but range up to 10 meters. The conglomerate is generally poorly sorted. Mud, silt, and sand sized matrix forms from ten to fifty percent of the volume, with an average around 30 percent.

The angular to rounded conglomerate clasts range in diameter up to 25 centimeters, but are much more commonly 2.5 to 7 centimeters. The whole Klamath Mountains suite of sedimentary, metamorphic, and sialic to mafic igneous rocks are represented in the clasts. Many of these appear to be locally derived, but others were probably transported from the south, where such rocks are known.

An outcrop of conglomerate along the southern boundary of the Canyonville fault zone in the northern parts of sections 11 and 12, T31S, R8W, bounded by serpentine on the north and a sheared, poorly exposed contact with the Dothan Formation on the south, may be a local variant of the Bushnell Rock Member. The eastern part of this exposure is very coarse conglomerate with poorly rounded boulders more than a meter in diameter. The coarse unit is well cemented, and unfossiliferous, and the clasts are entirely locally derived serpentine, phyllite, and greenstone. The matrix is dark green, similar to Peterson's (1957) locally dark green iron and manganese oxide rich matrix in the same nember in the southeast quarter of the Camas Valley quadrangle immediately to the 
north. The conglomerate at the west end of the slice in the northeastern part of section 11 is similar in composition but not as coarse. A similar conglomerate, also apparently Bushnell Rock Member, occurs near the base of the member in the northwestern quarter of the Dutchman Butte quadrangle. In the central part of the slice the conglomerate is less indurated and has a great variety of better rounded clasts of lithologies characteristic of the basal Lookingglass conglomerate. Finer interbeds contain plarit fragments and local coal lenses (Fig. 7). If the conglomerate in the central portion of the slice is equivalent to the locally derived section at each end and not to an overlying unit, the whole slice is the southernmost and coarsest exposure of the Bushnell Rock Member in the map area.

Tenmile Member. In most places, where visible, the Bushnell Rock conglomerate is overlain by mudstone, siltstone, and minor thin sandstone beds of the Tenmile Member. Locally, as at Table Mountain, the conglomerate is overlain by a thin section of sandstone with minor mudstone which is in turn overlain by the sandstone and conglomerate of the Olalla Creek Member.

The contact between the Tenmile and Bushnell Rock members is gradational. Mudstone and sandstone interbeds appear in and interfinger with the upper part of the 


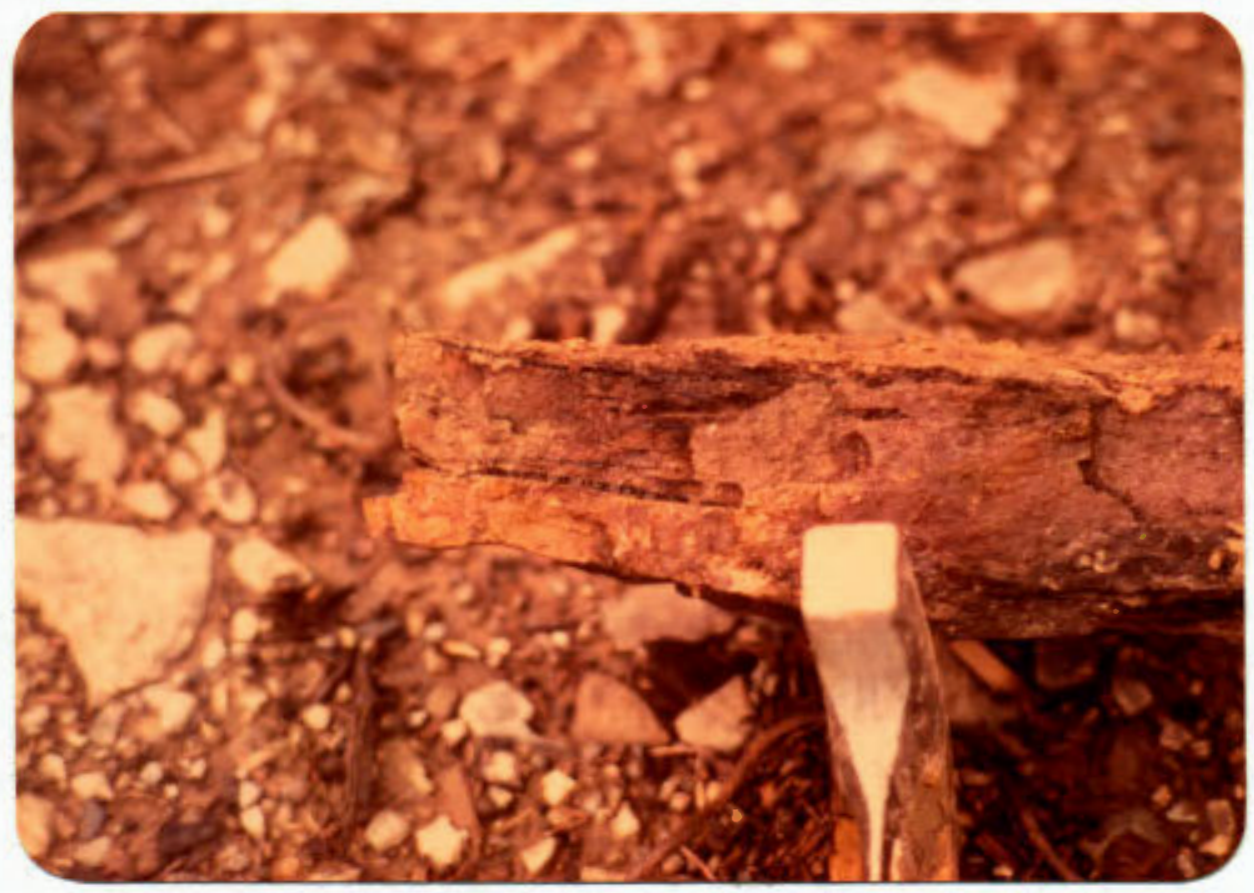

Figure 7. Minor coal lenses in finer interbed of Bushnell Rock Member conglomerate in section 11, T31S, R8W. 
Bushnell Rock conglomerate. The conglomerate and sandstone interbeds die out upward, typically giving way to a thick mudstone and siltstone section. However, in the northwest part of the map area, locally conglomeratic sandstone interbeds persist throughout much of the Tenmile Member. The mudstone and siltstone section varies from thinly bedded to massive, but the massive appearing sections may result from destruction of visible bedding by landsliding. Many of the sandstone interbeds are lenticular, suggestive of channel deposits. Northeast of Big Dutchman Butte, the locally pebbly sandstone channel deposits are strongly graded laterally as well as vertically and are suggestive of local, meandering, possibly fluvial channel deposits (Fig. 8). Soft-sediment slump features are visible in many outcrops (Fig. 9). The Tenmile Member mudstone section thickens rapidly to the northwest in the study area (cross-section $A-A^{\prime}$, Fig. 2 and Fig. 1). If such thickening did not occur, the Bushnell Rock Member would be exposed in the large north-trending anticline in the western part of the map area. Along this structure, named the Bear Creek anticline by Peterson (1957), the mudstone section of the Tenmile Member has thickened from essentially zero at Buck Rock and Table Mountain to at least 1200 meters (see cross-section D-D', Fig. 2).

Near Table and Buck Mountains and along upper Table Creek, the Tenmile Member mudstone section is replaced by 


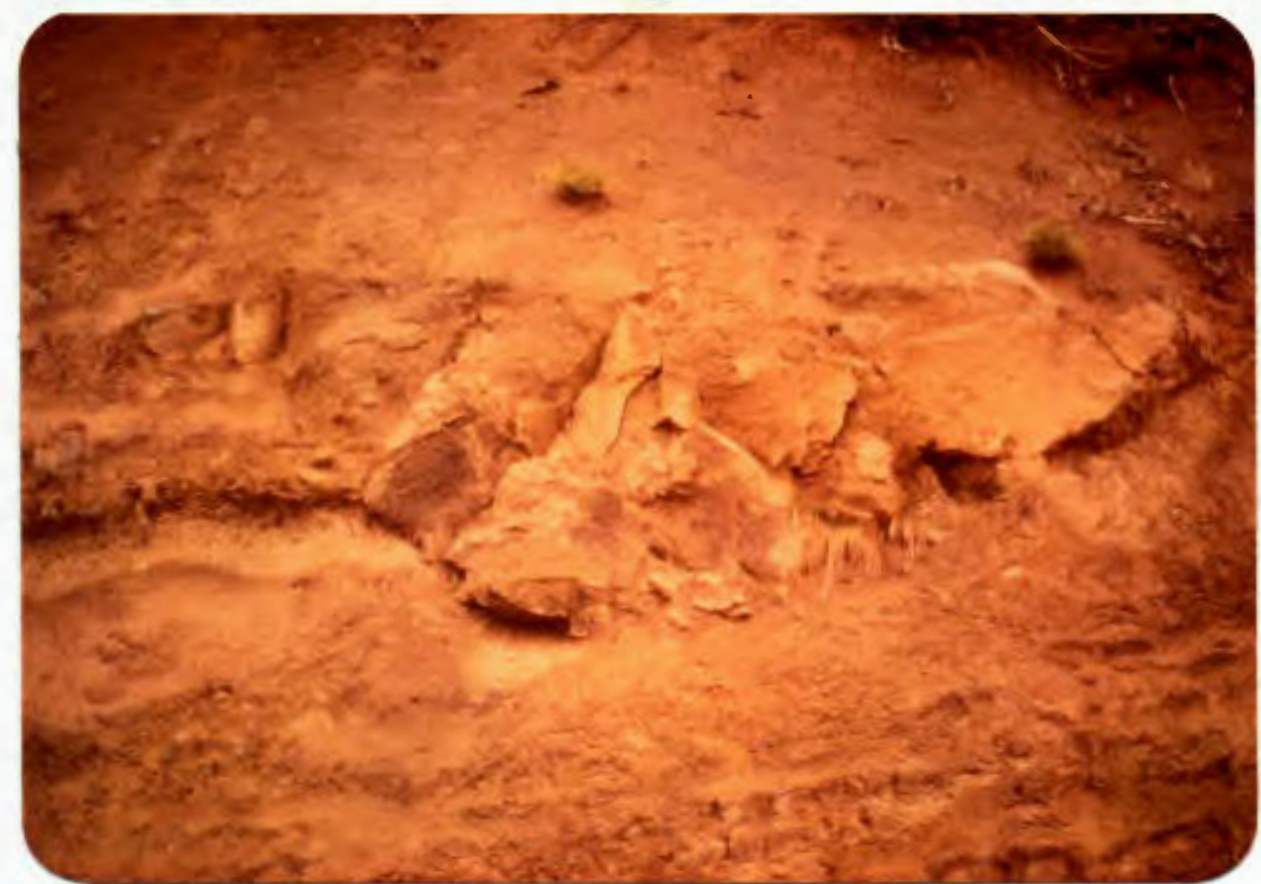

Figure 8. Sandstone channel in roadcut northeast of Big Dutchman Butte.

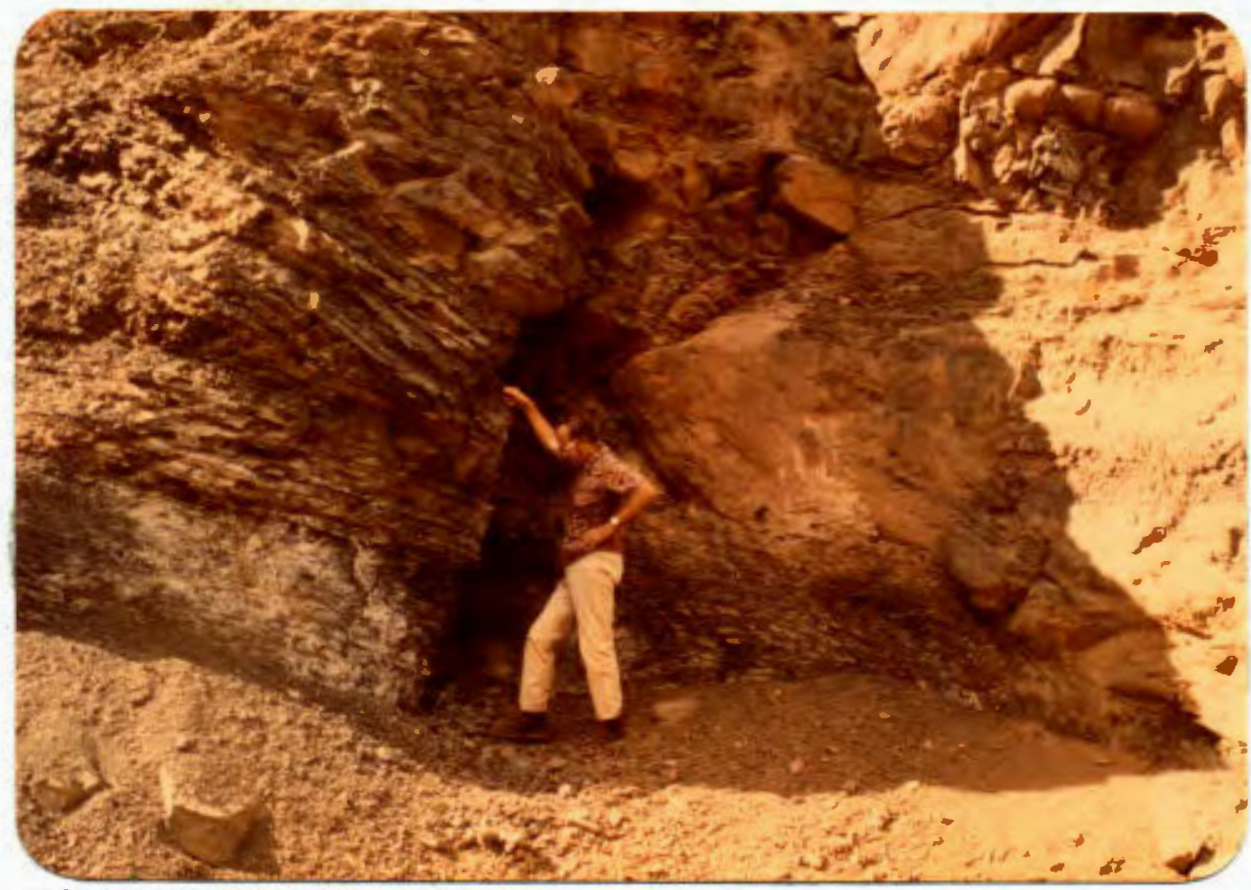

Figure 9. Dr. Baldwin stands next to a soft-sediment slump feature in Tenmile Member north of Horse Prairie, central thesis area. Such features are common throughout the Tenmile Member. 
a thin sandy section which contains plant, gastropod, and pelecypod fossils. This is probably a local facies change which near the head of Table Creek appears to have been controlled by an east-west fault (Fig. 1).

The Tenmile Member locally interfingers with the overlying Olalla Creek Member, as it does with the underlying Bushnell Rock Member. In the western part of the study area, the contact of the Tenmile and Olalla Creek Members is arbitrary. The Tenmile Member contains increasingly numerous conglomerate and sandstone lenses until these coarser beds dominate the upper part of the section.

Olalla Creek Member. The upper member of the Lookingglass Formation in the map area consists of coarse, locally pebbly sandstone and conglomerate with siltstone and mudstone interbeds. This member caps Table Mountain, the ridge including Live Oak Mountain and Big Dutchman Butte, and much of the northern valley of olalla Creek. The member was named by Baldwin (1974) for the section along Olalla Creek. The member ranges to more than 100 meters at Table Mountain. Immediately to the west of the map area, the member thickens rapidly to more than 1000 meters before it disappears underneath the Fluornoy Formation. Sandstone beds, locally pebbly, dominate the olalla Creek Member throughout most of the map area (Fig. 10), although coarse conglomerate, assigned to 


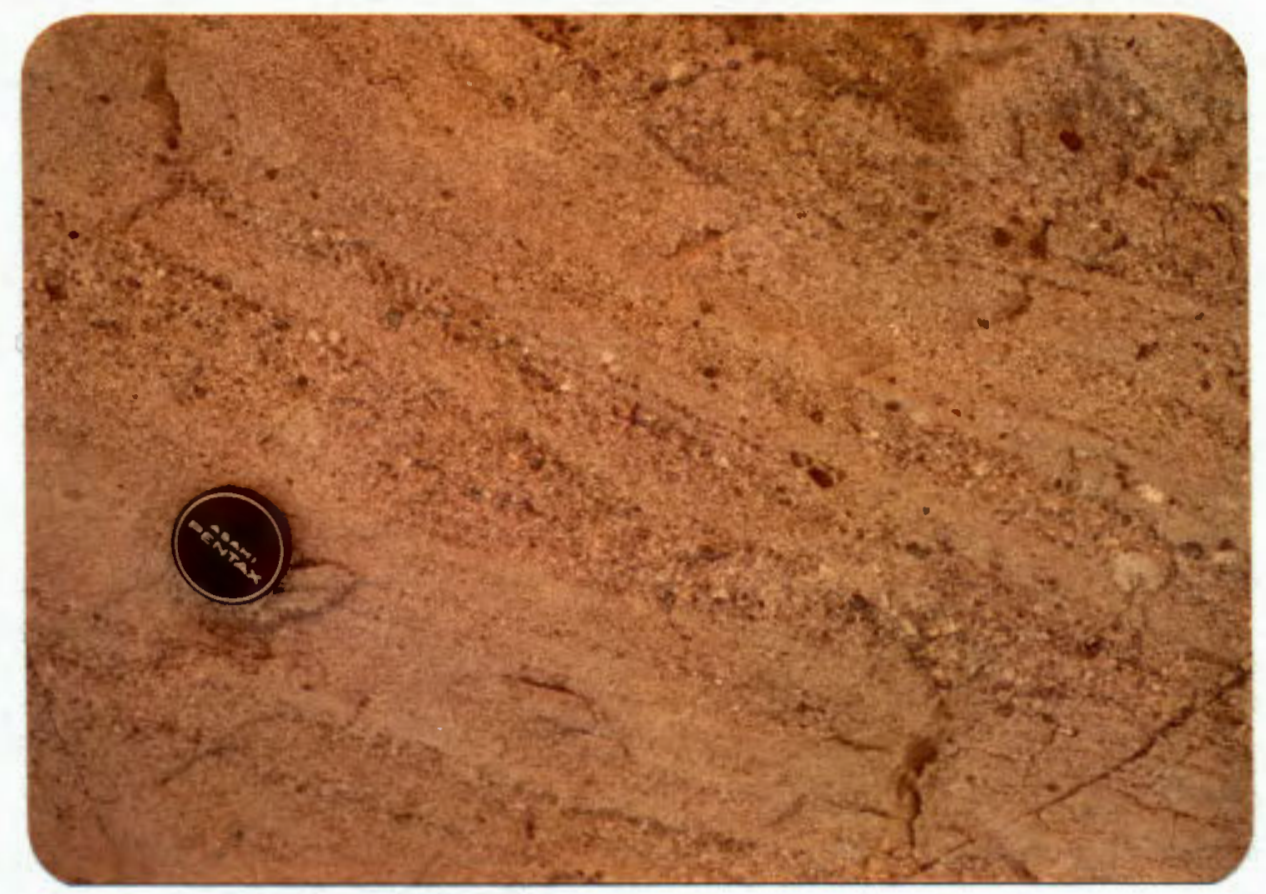

Figure 10. Pebble and sandstone lenses showing channel scour and fill in Olalla Creek Member. Outcrop is in northwest corner of map area. 
this member, caps Big Dutchman Butte. Bed thicknesses range from a few centimeters to a few meters, with a general increase in thickness with increase in coarseness. Bedding ranges from well developed and regular, mainly in the eastern part of the study area, to poorly developed and irregular to the west. Just south of the confluence of the Olalla Creek and Thompson Creek, a thick sandstone is exposed with crossbedding which indicates deposition by north-flowing currents.

The composition of the Olalla Creek Member is similar to that of the Bushnell Rock Member, and where the Tenmile Member is absent, the break between the upper and lower members of the Lookingglass Formation is difficult to place. The break between the members may be represented only by a finer grained sandstone section which is thin and poorly exposed. Generally, the olalla Creek Member is not as coarse, has better bedding, contains fewer channel deposits, is better sorted, and more fossiliferous than the Bushnell Rock Member. The Olalla Creek Member, locally contains gastropod, pelecypod and plant fossils.

The Olalla Creek Member of the Lookingglass Formation is the uppermost unit in the thesis area. A short distance to the northwest, it is unconformably overlain by the midale Eocene Fluornoy Formation. 
UNITS WITHIN THE CANYONVILLE FAULT ZONE

The Canyonville fault zone has been subdivided for mapping purposes into several belts according to predominant lithologies. Throughout the whole fault zone, however, diverse rock types are locally scattered. These isolated blocks are too small, poorly exposed, and complexly intermixed to be shown on the map (Fig. 1). The following descriptions review the dominant rock types of each belt shown on Figure 1. The Canyonville fault zone continues under the Lookingglass Formation but whether the belts described below extend far westward is problematical.

\section{Southern Serpentine BeIt}

The southernmost unit of the zone is a dominantly serpentine belt. This serpentine belt contains local peridotite and greenstone bodies, and, less commonly, small masses of dacite (for a more detailed description of the petrology of the serpentine and associated rocks of this belt and the other serpentine, peridotite, and greenstone belts, the reader is referred to cornell, 1971). Associated with this belt, especially in the southern part, are slices of sedimentary rocks. These sedimentary slices include thin, contorted, finegrained chert beds (good examples of both are along 
the Cow Creek road south of Iron Mountain). The conglomerate and coarse sandstone of the Bushnell Rock Member of the Lookingglass Formation in Sections 11 and 12, T31S, R8W, may also be a similar slice.

2. Riddle Belt

The next belt contains large slices of Riddle Formation rocks. These slices are generally surrounded and apparently underlain by the serpentine and associated rocks of the southern and middle serpentine belts. However, the serpentine surrounding the Riddle slices is more subdued than the serpentine of the southern and middle serpentine belts.

3. Midale Serpentine Belt

This linear belt contains the most prominent of the map area's serpentine exposures. Included within the serpentine are pods of greenstone, peridotite, diabase, dacite, and quartz diorite.

\section{Greenstone Belt}

The greenstone belt is actually a mixed belt of meta-igneous, metavolcanic, and metasedimentary rocks in a serpentine matrix. The greenstones are predominantly chloritized diabase or basalt, volcanic breccia, and tuff 
(Cornell, 1971, p. 20). This belt may represent an extension or slice of Kent's (1972) and Johannssen's (1972) Rogue Formation.

Intermixed with the greenstone are local phyllitic schists and relatively unmetamorphosed sediments. A pod of thinly bedded sandstone and shale similar to Cornell's southern Dothan Formation occurs near the south end of the Byer's bridge (Sections 33 and 34, T30S, R7W).

5. Peridotite Belt

A strong change in morphology and vegetation on the photos in the northern part of the belt appears to mark an increase in peridotite and serpentine, although some metasedimentary and metavolcanic pods are also present. The peridotite is locally very coarse, as in the southeastern part of section 28, T30S, R7W. The peridotite is divided by a mapped fault into a more sparsely vegetated northern part and a southern part. The sparser vegetation in the northern part may possibly be due to decreased calcium content (Robert Coleman, personal communication, 1976). The peridotite reappears to the west beneath the overlying Lookingglass Formation in Section 6, T3IS, R7W, immediately north of the middle serpentine belt. It may be that this peridotite is local or that the greenstone dominated belt truncates under the Lookingglass Formation. 
6. Otter Point Formation Belt

Rocks assigned to the Otter Point Formation, which crop out in a belt to the north of the peridotite, are dominated by phyllite, sandstone and chert. This terrain also contains linear serpentine exposures including one which divides it, as well as locally numerous pods of scattered igneous and meta-igneous rocks. The Otter Point rocks in the thesis area resemble those of the Otter Point Formation to the west and north. They are typically more variable, and have a greater portion of finer-grained rocks than the Dothan. In addition, they are more variably metamorphosed than the Dothan and contain blocks of higher grade metamorphic rocks (Coleman and Lamphere, 1971). The Otter Point rocks are disordered and could be classified as melange (Hsu, 1968).

\section{Northern Serpentine Belt}

A linear, northeast trending, continuous belt of serpentine bisects the Otter Point belt and locally forms the boundary between the otter Point Formation and the Riddle Formation to the north (see Fig. 1). This belt flares out in the northern corner of the study area and to the northeast to include a large peridotite pod in upper Thompson Creek. 


\section{STRUCTURAL GEOLOGY}

The structural geology of the thesis area includes three distinct trends: (1) the regional N4OE grain (see Fig. 1) of the pre-Tertiary formations; (2) the easterly trend of the Canyonville fault zone; and (3) the northerly to northeasterly fold trends in the less deformed Lookingglass Formation and in the younger Fluornoy and Tyee Formations to the north and west of the map area.

Development of the N4OE grain may have continued through Roseburg and even into Lookingglass time, based on regional patterns of attitudes (Perttu and Benson, in prep.). This deformation consisted of reverse faulting, associated folding on all scales up to regional complex asymmetric anticlines, and synclines, and pervasive shearing, especially of the pre-Tertiary units. Deformation is progressively less severe upward in section, with the Eocene formations much less deformed than the older units. The large regional folds are easily observable only in the Eocene units because of relatively moderate deformation. 
To the north and northwest of the map area (e.g., Baldwin, 1974), warping along northerly to northeasterly trending lines and associated minor normal faulting of the Fluornoy and Tyee Formations as well as the upper Lookingglass Formation (personal mapping to the north) represent a later period of much gentler deformation. The Lookingglass Formation shows part of the transition between the earlier northeasterly deformation and the younger more northerly warping.

The Canyonville fault zone locally controls the distribution of the Klamath Mountains Province and Coast Range Province. Before Lookingglass time, and possibly before Roseburg time, extensive right-lateral faulting characterized the zone. Right-lateral faulting was followed by down-to-the-north faulting in Lookingglass, and possibly into post-Lookingglass time. During Riddle and Days Creek time and again in early to middle Eocene time, the Canyonville fault zone formed the southern shoreline of a marine embayment.

\section{PRE-TERTIARY REGIONAL STRUCTURE}

Away from the Canyonville fault zone, the Jurassic through lower Eocene formations of the area are sheared, folded and faulted along a roughly N4OE trend (Fig. 11). These trends are reflected in the thesis area in the 


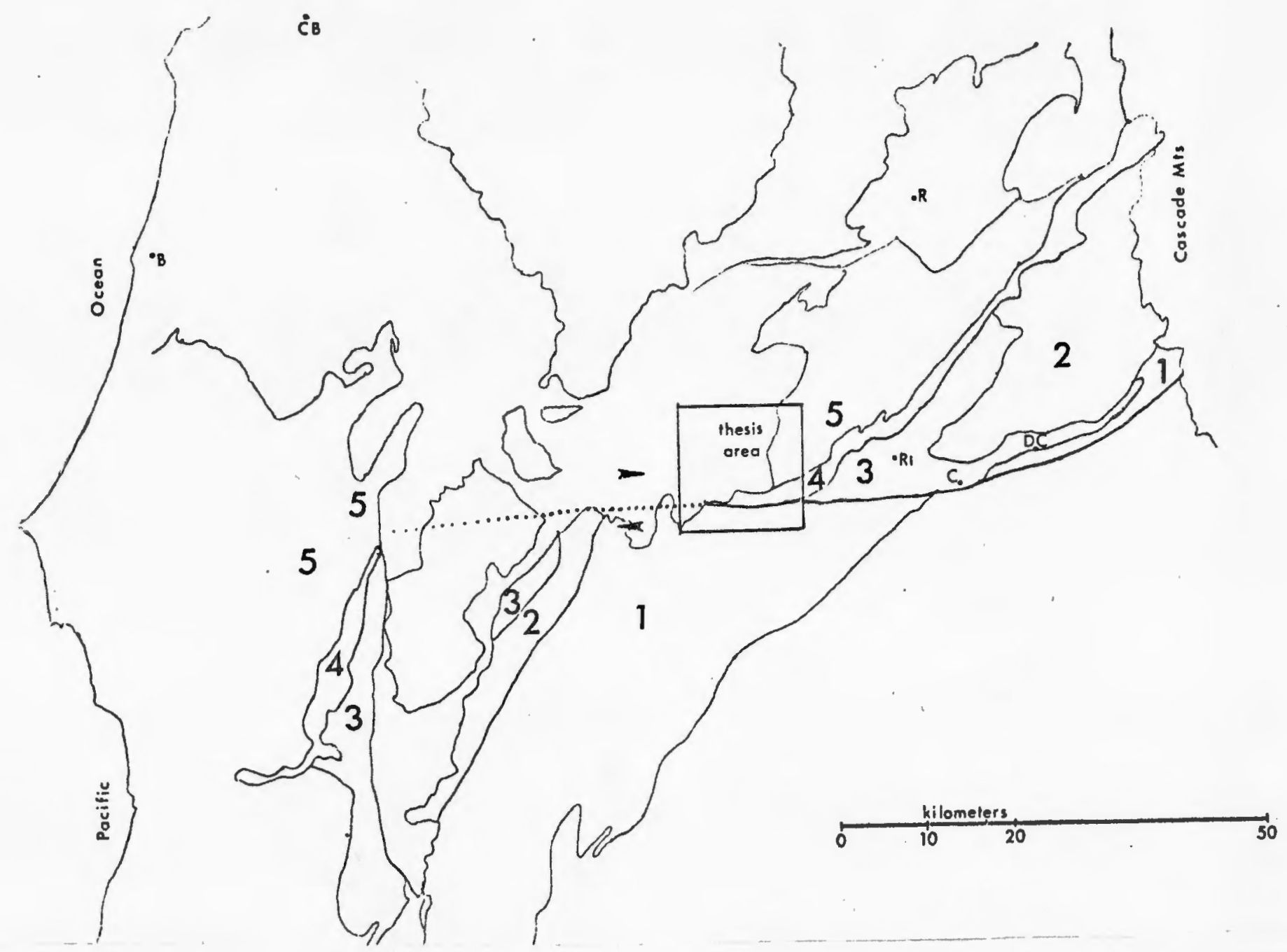

Figure 11. Regional geologic setting and possible correlations across Canyonville fault zone. Key to generalized geology: 1) Dothan Formation; 2) "Western" Rogue Formation; 3) Myrtle Group; 4) Serpentine, peridotite belt; 5) Otter Point Formation. $\mathrm{B}=$ Bardon; $\mathrm{C}=$ Canyonvilie; $\mathrm{CB}=$ Coos Bay; $\mathrm{DC}=$ Days Creek; $\mathrm{Ri}=$ Riddle; $\mathrm{R}=$ Roseburg. 
strike of beds of the Dothan Formation (Fig. 1). No attempt was made to unscramble the internal structure of the Dothan; this topic is being studied by Gerald Black in the southeast quarter of the Dutchman Butte quadrangle. In summary, the Dothan Formation has been severely sheared, faulted, and folded in folds and offsets of varying magnitudes. The deformation apparently accompanied extensive reverse faulting of the formation (e.g., Coleman, 1972):

\section{CANYONVILLE FAULT ZONE}

The Canyonville fault zone trends east to east-northeast (Figs. 1 and 11). The southern part of the zone is more obviously linear and east trending shearing and faulting are more pronounced. The southern boundary fault of the zone separates the Dothan Formation on the south from the Myrtle Group, the Roseburg Formation, and Bushnell Rock Member of the Lookingglass Formation. The zone in general forms the southern boundaries of the otter Point Formation and of the Tertiary Coast Range basin in and near the study area. The zone is a fundamental structure which persisted from Jurassic into Tertiary time. It consists of faults and shears of all scales. Slices or belts within the zone are generally bounded by serpentine. Faults of the Canyonville zone offset all 
the formations of the map area, although the Lookingglass Formation, and especially the Olalla Creek Member; is considerably less displaced than are the older formations. Deposition of the Myrtle Group and of the Roseburg and Lookingglass Formations was locally controlled by the zone boundary. No Myrtle Group rocks have been mapped south of the zone; the Myrtle Group rocks near the zone are shoreline facies rocks. The Roseburg and Lookingglass Formations rocks near the zone are of shoreline and shallow water facies. The Lookingglass Formation thickens northward across the zone (see Fig. I and cross-sections of Fig. 2). Dothan and Otter Point deposition may have been effected by the faulting, but this cannot be demonstrated within the study area. Pre-Lookingglass movement on the zone was rightlateral, with possibly 40 kilometers or more of displacement. Figure 11 shows a possible correlation of displaced units across the zone.

Based on my interpretation of the regional geology, the fault zone may have connected two active trench segments. The changes in facies, thickness, and distribution of the Myrtle Group and early to middle Eocene rocks suggest that the zone formed the southern boundary of a regional Jurassic to Eocene embayment. 
By Lookingglass time, right-lateral movement along the zone was replaced by down-to-the-north displacement. The Lookingglass Formation, where it overlaps the zone, shows both fault displacements and facies changes. Overall, the sense of displacement across the zone is down-to-the-north, although on individual faults, offsets may vary. Facies changes in the Lookingglass Formation reflect this sense of zone movement. The zone was active during the deposition of the formation, but activity along the zone decreased during Lookingglass time, as reflected by the lesser deformation of the olalla Creek Member, relative to the Tenmile and Bushnell Rock members. Displacements appear to have been concentrated more in the southern part of the zone in Lookingglass time, as reflected by the number of faults cutting the formation between Big Dutchman Butte and Chipmunk Ridge (Fig. 12). The abrupt termination of northerly structural grain along the westerly trend through Table Mountain and Live Oak Mountain is probably controlled by a strong westerly fabric in underlying rocks, which made westerly shear deformation easier than north trending folding.

\section{LOOKINGGLASS STRUCTURE}

The structure of the Lookingglass Formation in the map area is dominated by large open north trending folds and local north to northeast trending faults, except 


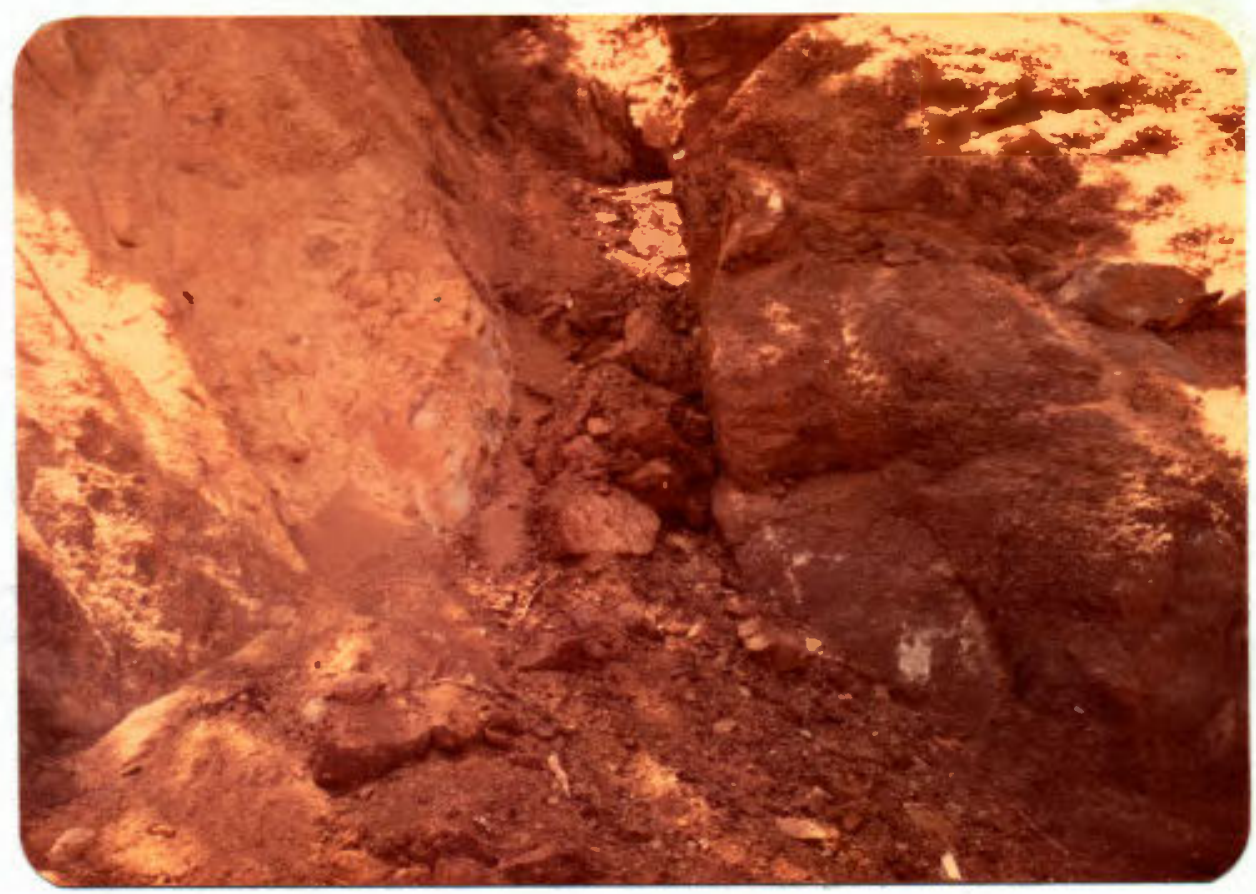

Figure 12. East-trending normal fault north of Big Dutchman Butte juxtaposes Olalla Creek Member conglomerate on right against finer grained Tenmile beds on left. 
along the Canyonville fault zone. Deformation in the formation decreases upward; the Olalla Creek Member is less deformed than the Bushnell Rock Member. Several structures which cut the Bushnell Rock Member do not disturb the Olalla Creek Member (e.g., the Table Creek fault, see Fig. 1). The two dominant Lookingglass folds of the map area are the Bear Creek anticline and the olalla syncline.

Bear Creek Anticline

The large asymmetric anticline to the northeast of Live Oak Mountain was named by Peterson (1957) for Bear Creek in the extreme northwest corner of the map area. If the anticline is really the southward extension of Peterson's fold, its axis lies somewhat east of Peterson's projected axis of the Bear Creek anticline. There are possible reasons for the lack of fold continuity. It may be an en echelon extension of Peterson's fold. Or, if the Bear Creek anticline is a continuation of Peterson's fold, the fold axis had to swing into a more northerly trend from his northeasterly trend, which may in part account for the apparent offset. The northeast trending Bear Creek fault mapped in the northwest corner of the thesis area may offset the anticlinal axis left-laterally about 900 meters. Drag effect of the fault on the anticline may account for the apparent offset. 
The anticline is asymmetric with the west limb steeper. Peterson (1957) mapped a high angle reverse fault along the west limb of his Bear Creek anticline which is consistent with the asymmetry here, and local faulting may occur in the same sense along the west limb of the fold in this map area. This is suggested. by locally steep westerly dips and straight ridges, but no direct evidence of faulting could be found.

The Tenmile Member forms the core and the Olalla Creek Member the flanks of the anticline. The possible offset southward extension of the fold southwest of Live Oak Mountain exposes Roseburg Formation in its core and the Bushnell Rock Member of the Lookingglass Formation on its flanks. The east limb of the anticline terminates near Live Oak Mountain, but the west limb continues south almost to Big Dutchman Butte. The westward dipping limb may locally rest unconformably on the older members of the Lookingglass Formation. The change from generally northerly strikes in the east limb of the Bear Creek anticline at Live Oak Mountain and in the Olalla syncline of Table Mountain to easterly strikes and gentle dips suggest control by the Canyonville fault zone, where, locally, deformation was more easily accomodated by east trending folds and faults. The west limb of the Bear Creek anticline is also the east limb of a large syncline which is west of the study area. The west dips 
may continue south of Live Oak Mountain because the synclinal fold is either younger or more fundamental than the Bear Creek anticline.

The rapid thickening of the Olalla Creek Member into the syncline suggests that the fold was more active during Olalla Creek time than the Bear Creek anticiline and Olalla syncline to the east. Neither of the eastward folds affects the Olalla Creek Member as much as does the syncline west of the map area, although both affect the older Tenmile Member considerably. In the two folds to the east there is considerable unconformity between the Bushnell Rock Member and the Olalla Creek Member.

The syncline to the west of the study area was studied in reconnaissance. The syncline seems to coincide with an Eocene drainage system along which was deposited a thick section of locally very coarse, apparently fluvial, deltaic sediments. Current directions were generally northerly. The coincidence of the drainage system and the syncline suggest structural localization of the drainage system. Apparently the drainage system was active throughout Lookingglass time, further suggesting that the syncline is a more fundamental structure than is the Bear Creek anticline. The swing of the Bear Creek anticline from its more northeasterly trend north of the study area into a 
northerly trend in the study area may be controlled by stratigraphy. The anticline in the study area follows the boundary of the much thicker and coarser Lookingglass section to the west of the anticline and the thinner Lookingglass section in and east of the anticline. It would have been mechanically easier to fold the thinner, finer grained Lookingglass section, causing the anticline to locally swing from its regional northeasterly trend and remain in the more easily deformed Lookingglass section.

\section{Olalla Syncline}

This syncline, the northward extension of which is described by Peterson (1957), is actually a local elongate basin with a north-trending long axis. The northern part of the basin is in Peterson's map area to the north; the southern margin of the basin is outlined by the crescent-shaped top of Table Mountain. The axis of the fold controls the north-flowing section of Olalla Creek.

The three members of the Lookingglass Formation form the limbs of the fold, although the mudstone and siltstone of the Tenmile Member are thin to absent on the southern and eastern sides of the fold. The interior of the fold contains the type locality of the olalla creek Member (Baldwin, 1974). Local windows through the member 
expose the Tenmile Member which thickens abruptly. northwestward into the syncline (Fig. 2).

\section{Table Creek Fault}

The east-trending fault south of Live Oak Mountain and Horse Prairie is named after Table Creek, which crosses its eastern margin. This fault is probably controlled by the underlying Canyonville zone. The fault is actually a combination of a steeply dipping (probable reverse) fault and anticlinal fold. The structure is best seen along the west side of the hill at the boundary of sections 35 and 36 south of Horse Prairie.

The Table Creek structure forms the northern termination of the north-trending anticlinal segment in section 34 (Fig. 1). The anticlinal segment, which may be a southward extension of the Bear Creek anticline, in turn helps eliminate the Table Creek structure to the east. At the core of the anticlinal segment, Roseburg Formation rocks are faulted against Tenmile Member rocks to the north. Eastward, along the east limb of the anticlinal segment, progressively less offset exists across the Table Creek structure until the structure apparently becomes more a north-side-down monocline near the head of Table creek. The west end of the Table Creek structure disappears beneath the 
Lookingglass which forms the north-trending ridge to the west. The Lookingglass of the ridge postdates the Table Creek structure and unconformably overlies it. The fault continues west of the ridge in the northwest quarter of the Dutchman Butte quadrangle and on into the Bone Mountain quadrangle.

The Table Creek structure probably locally controlled deposition of the Tenmile Member of the Lookingglass Formation. The thick mudstone of the member may have deposited in a local structural basin of which the Table creek fault was the southern margin.

East Trending Faults

Several east-trending faults associated with the southern boundary of the Canyonville fault zone juxtapose slices of Bushnell Rock Member, Riddle Formation and serpentine. These faults are covered to the west by a large landslide mass northeast of Big Dutchman Butte. Apparently small faults in the same trend are visible in the Olalla Creek Member north of Big Dutchman Butte, and are probably the continuation of the zone. Although offsets of the Olalla Creek Member are not as large as those of the Bushnell Rock Member, the presence of faults in the Olalla Creek Member demonstrates that the zone was still active in post-Lookingglass time. 
Bear Creek Fault

The Bear Creek fault trends northeastward in the northwest corner of the study area southeast of Bear Creek. The fault is exposed along the ridge top in the northwest corner of section 10, T30S, R8W. The extension of the fault northeastward is based partially on morphology and partially on geology. In the exposure of the fault in section 10, the northwest side of the vertical fault appears to be up. If the fault continues with the same sense of offset, it may help account for the apparently very thin section of Lookingglass Formation in Peterson's (1957) Bear Creek anticline and exposures of pre-Tertiary rocks in its core a short distance north of the thesis area. The Bear Creek fault, combined with Peterson's larger Tenmile fault would locally uplift the Bear Creek anticline to expose the older rocks in the structure's core.

The Bear Creek fault may offset the axis of the Bear Creek anticline left-laterally about 900 meters, so the fault movement would be both vertical and lateral. 
GEOLOGIC HISTORY

REGIONAL HISTORY

The following geologic history of the region is partially my reinterpretation of the geology of the region.

In Late Jurassic time, trench and slope sediments were deposited on a subducting sea floor of "western Rogue Formation" (the Rogue in Kent's (1972) area, and in the large triangular exposure north of Days Creek to the east of the thesis area). The sediments and volcanics of the otter Point Formation accumulated near the trench, while the Dothan Formation sediments probably accumulated on the slope, and possibly locally on the shelf (Fig. 13A).

The Otter Point and Dothan sediments were probably deformed as they accumulated as well as after deposition, because of continued underthrusting along the continental margin. Before the deposition of the Myrtle Group, the western Rogue seafloor was obducted relative to the otter Point and Dothan Formations (Fig. 13B,C). Possibly some of the volcanic blocks in the otter Point Formation were derived from the "western Rogue Formation" during its obduction (Fig. 13A). 
A

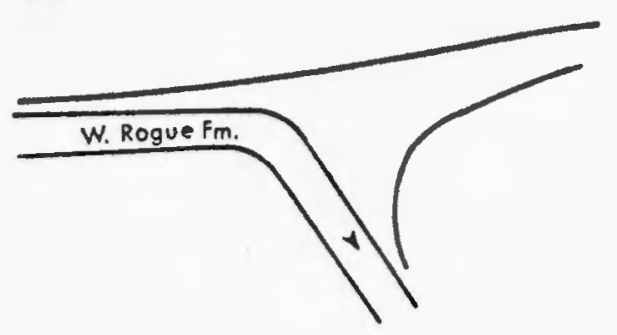

C

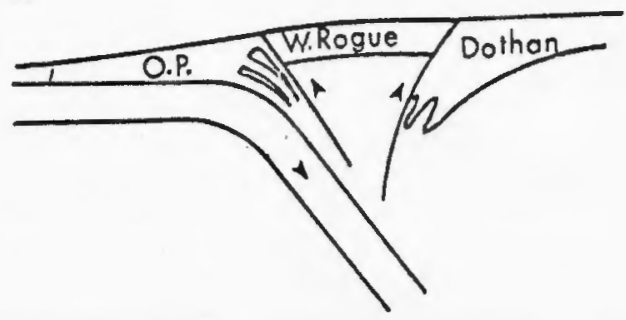

B

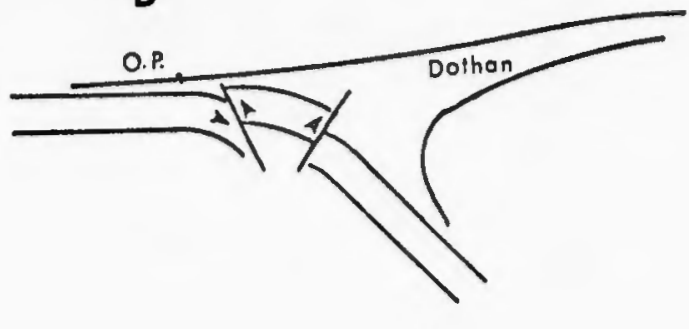

D

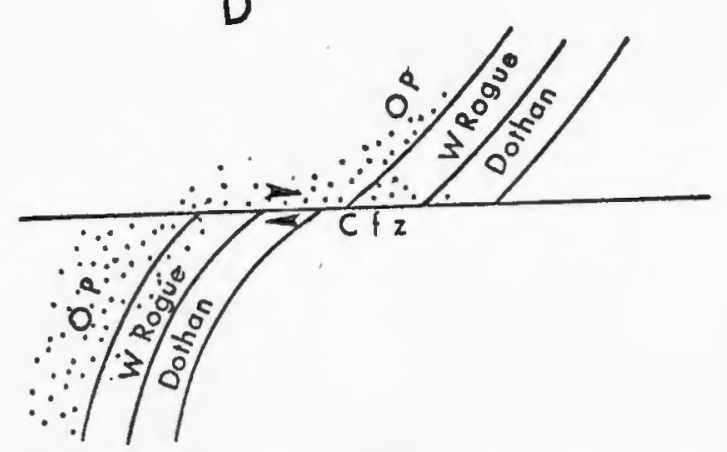

Figure 13. Schematic of geologic history of the Canyonville fault zone. A) Upper Jurassic cross section: subducting oceanic plate of W. Rogue Fm. and related lithologies under continental margin; B) obducting slice of W. Rogue Fm.; C) Obducted oceanic plate slice separates Otter Point and Dothan terrains; D) Uppermost Jurassic and Lower Cretaceous map view: Otter Point, $W$. Rogue, and Dothan terrains offset by Canyonville fault zone movement. Stippled pattern indicates deposition of shoreline Myrtle Group deposits over older units. (Fig. 13 continued on next page). 

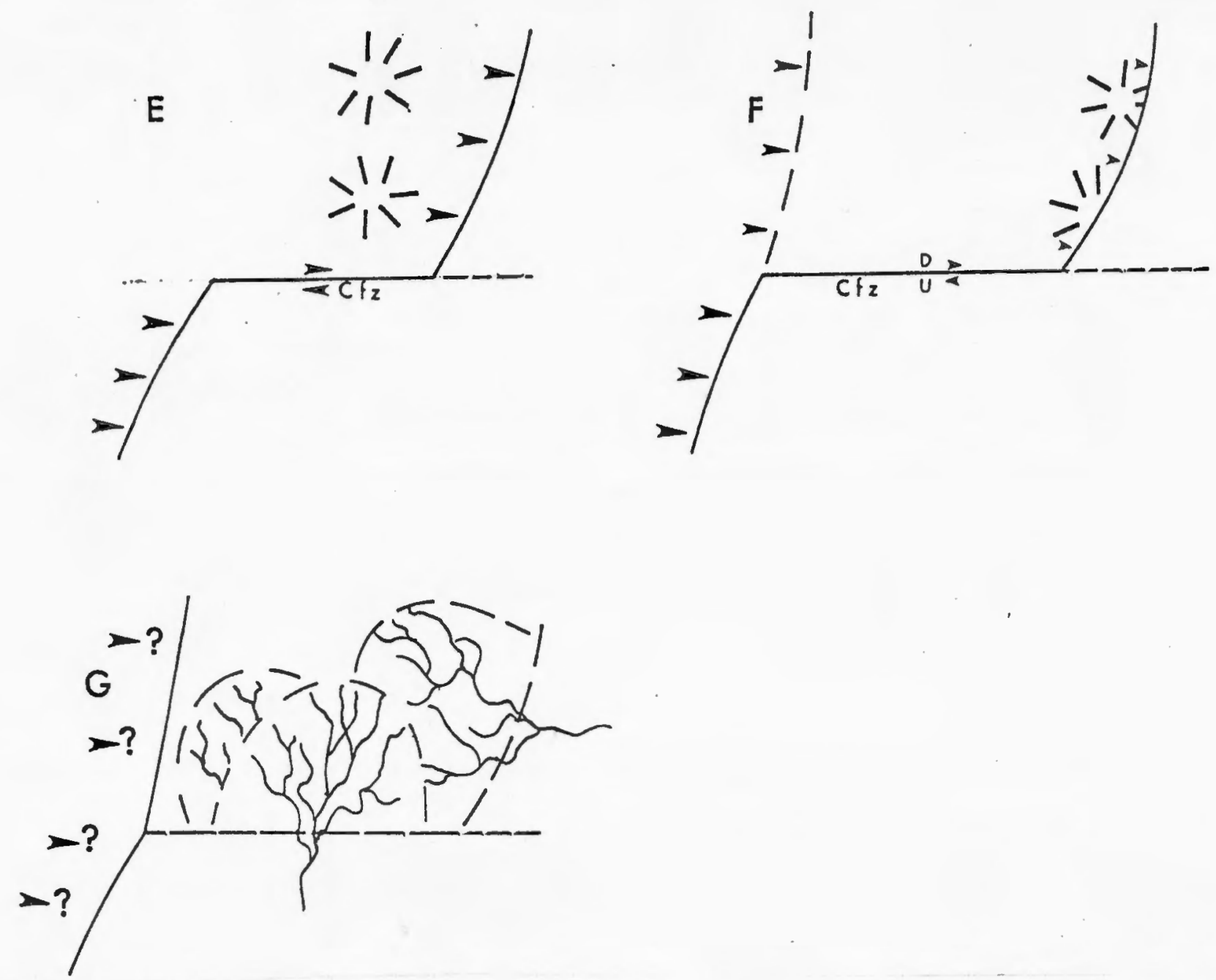

Figure 13 (continued). E) Roseburg time: right lateral movement continues. Zone forms continental shoreline; F) Lookingglass time: subduction zone jumps by change in plate motion or jamming by Roseburg volcanics; G) Fluornoy and Tyee Formations build out over now inactive continental shelf and slope. 
Shortly after deposition and initial deformation of the Otter Point and Dothan Formations and obduction of the western Rogue, right-lateral faulting began along the Canyonville fault zone. The faulting probably offset two active trench segments (Fig. 13D).

As a result of the right-lateral faulting, the Canyonville fault zone locally formed the latest Jurassic and Early Cretaceous shoreline. Along and near this shoreline, the Myxtle Group sediments were deposited as near shore and probably locally as nonmarine fluvialdeltaic sediments (Fig. 13D). Right-lateral movement along the zone, as well as regional subduction in the offset trench segments, with accompanying deformation, continued, possibly sporadically, deforming the Myrtle Group rocks.

By Lookingglass time, the right-lateral movement along the Canyonville fault zone was replaced by vertical displacement (Fig. 13F). Regionally, southeast to northwest compressive deformation parallel to the preTertiary was ending, possibly because subduction along the continental margin was ending locally or because in Roseburg and Lookingglass time, the subduction zone in western Oregon was shifted westward to a position west of the present shoreline (Fig. 13E,F). A possible fix on the timing of the proposed westward stepping of 
subduction would be: Roseburg time, active subduction; Lookingglass time, westward stepping of subduction, end of associated compressive deformation; Fluornoy and Tyee time, northward building of deltaic deposits across a now inactive shelf and slope (Fig. 13G).

\section{LOCAL HISTORY}

Within the study area, the role of the Canyonville fault zone as a basin boundary and as an indicator of decreasing deformation during Lookingglass time is worth examining. From south to north across the zone the basal Lookingglass goes through successive changes which suggest that the southern boundary of the Canyonville zone was an abrupt north facing slope. At Big Dutchman Butte, the basal unit of the Lookingglass is not conglomerate, but rather possibly fluvial, channel-deposited, pebbly sandstone and siltstone beds which rest unconformably on the Dothan Formation. The basal Lookingglass, the Bushnell Rock Member in sections 11 and 12, T31S, R8W, north of Union Creek is mainly a locally derived coarse, angular conglomerate. Northward from Table Mountain, the Bushnell Rock Member pebbles and cobbles are generally not as coarse, better rounded, and of more diverse lithology. 
The Tenmile Member goes through thickness and facies changes which suggest both structurally controlled northward basining and folding of the member at the time of its depositton. South of the Table Creek fault and along the south and east margins of the Olalla syncline, the Tenmile Member is a thin, sandy, apparently shallow water facies. North of the Table Creek fault and into the Olalla syncline, the member abruptly thickens northwestward into a predominantly mudstone and siltstone section. A short distance north of Big Dutchman Butte, the Tenmile Member comprises channel-deposited, pebbly sandstone, siltstone and mudstone; but the section thickens abruptly northward across the Table Creek fault and changes to mudstone with intercalated local conglomeritic sandstone with extensive soft-sediment slump features. The possibly fluvial facies of the Tenmile Member at and west of Big Dutchman Butte in contrast to the facies to the east suggests that a fluvial-deltaic system existed to the west of the thesis area. The north-flowing system may have followed the trough of the previously mentioned syncline west of the map area.

The facies changes in the Tenmile Member in the map area may reflect changes from a fluvial-deltaic system to the west to near-shore sandstones and basin-deposited mudstone beds to the east and northeast. The channel- 
deposited sandstone and related fine-grained beds north of Big Dutchman Butte may be transitional in the west to east change of facies. The changes in the Tenmile Member suggest both that the Canyonville zone formed the southern boundary of the Tenmile depositional basin and that the structures of the zone were active during and locally controlled deposition of the Tenmile Member. The Table Creek fault and olalla syncline, for example, were probably active and caused the changes in the Tenmile Member associated with them.

The Olalla Creek Member also shows changes across the Canyonville fault zone, as well as rapid thickening northwestward from the Bear Creek anticline. At Big Dutchman Butte, the Olalla Creek Member is coarser than anywhere to the north of the southern boundary of the Canyonville zone in the map area. In the same manner, the Olalla Creek conglomerate appears to be coarser at Table Mountain than it is northwestward in the map area. Northwestward from the Bear Creek anticline, the member thickens dramatically west of the map area until it disappears under the Fluornoy Formation to the northwest (personal observation).

The rapid thickening of the Olalla Creek Member along the western margin of the map area and to the west, as well as bedding changes in the member suggest that the 
above-mentioned fluvial-deltaic system was also active during Olalla creek time. Similar changes in the older Roseburg and younger Fluornoy Formations suggest an even longer history to the system. The fluvial deltaic system may have drained a right-laterally offset (by the Canyonville fault zone) continental shelf to the south. The local thick sandstone in the core of the olalla syncline with cross-bedding which indicates northward flow, suggests that the fold may have been forming during Olalla Creek deposition, as well as afterward, to fold the member into its present attitude. Apparently by Olalla Creek time, the Table Creek fault was no longer active (Fig. 1). Similarly, the southern boundary faults of the zone locally offset the member but not as extensively as they offset the Bushnell Rock Member. The Olalla syncline does not affect the Olalla Creek Member rocks nearly as dramatically as the Tenmile rocks, suggesting at least temporarily lessened activity of the fold or more rapid deposition of the Olalla Creek Member.

The eastward deflections of the west-dipping olalla Creek Member ridge at Chipmunk Ridge and Live Oak Mountain suggest that post-olalla Creek northward downwarping may have continued along the Canyonville fault zone (Fig. 1). The faults north of Big Dutchman Butte may also be evidence for such movement. 
The Table Creek fault which was inactive by olalla Creek time appears to be a south-side-up reverse fault in outcrop, while at least two of the faults which cut the Olalla Creek Member north of Big Dutchman Butte are normal north-side-down faults. Presumably, at least locally the stress regime of the Canyonville fault zone changed during Lookingglass time, although northward basining continued.

The Olalla Creek Member across the Canyonville fault zone contains only moderate offsets. The Fluornoy and Tyee Formations cross the projection of the zone west of the study area with little or no apparent offset. The Canyonville fault zone thus became inactive during and shortly after Lookingglass time, during the time of the possible westward stepping of the subduction which may have been the cause of the compressive deformation of the Roseburg Formation and of the older formations (Perttu and Benson, in prep.).

\section{POSSIBLE ORIGIN OF THE CANYONVILLE ZONE}

The Canyonville fault zone may be related to postulated westward displacement of the Klamath Mountains block (e.g., Hamilton, 1969). The zone may be a northern mirror of Jones and Irwin's (1971) left-lateral displacement zones along the southern Klamath Mountains boundary. 
If the zone is related to Jones and Irwin's left-lateral faults, movement along the Canyonville fault zone began earlier (pre-Riddle Formation) than to the south, where it was post-Early Cretaceous (Valanginian). Westward displacement of the Klamath Mountains block relative to the continental margin to the north would have formed an embayment north of the Canyonville fault zone. Subduction along the continental margin would have given way to lateral faulting locally along the Canyonville fault zone where relative plate motion became more strike-slip than convergent. The Canyonville fault zone would then have become a transform fault connecting two active trench segments. The system could have become inactive when the subduction zone straightened, jumping westward, possibly because of "jamming" of the subduction zone by local volcanic piles of the Roseburg, Siletz River, and Crescent Formations. Alternatively, the subduction zone may have jumped westward because of a realignment of plate motions, and the westward jumping of subduction may have influenced the formation of volcanic piles (Fig. 12). The then inactive embayment would have been filled by the younger Fluornoy, Tyee, and other units. 


\section{SELECTED REFERENCES}

Baldwin, E. M., 1964, Geology of Oregon, 2nd Ed.: Eugene, Univ. Oregon coop Book Store.

- 1965, Geology of the south end of the Oregon Coast Range Tertiary Basin: Northwest Sci., v. 39, no. 3, p. 93-103.

1974, Eocene stratigraphy of southwestern Oregon: Oregon Dept. of Geol. and Mineral Indus. Bull. 83.

Baldwin, E. M., and Beaulieu, J. D., 1973, Geology and mineral resources of coos County, Oregon: Oregon Dept. of Geol. and Mineral Indus. Bull. 80 .

Black, G. I. (in prep.), Structural geology of the southeast quarter of the Dutchman Butte quadrangle, Oregon: Portland State Univ. masters thesis, unpub.

Coleman, R. G., 1971, Plate tectonic emplacement of upper mantle peridotites along continental edges: Jour. Geophys. Research, v. 76, p. 1212-1222.

, 1972, The Colebrook schist of southwestern Oregon and its relation to the tectonic evolution of the region: U.S. Geol. Survey Bull. 1339.

Coleman, R. G. and Lamphere, M. A., 1971, Distribution and age of high-grade blueschists, associated eclogites, and amphibolites from Oregon and California: Geol. Soc. America Bull., v. 82, no. 9, p. 2397-2412.

Cornell, J. H., 1971, Geology of the northwest quarter of the Canyonville quadrangle, Oregon: Univ. Oregon masters thesis, unpub.

Dicken, J. N., 1955, Oregon geography: Ann Arbor, Mich., Edwards Bros. Inc.

Diller, J.S., 1898, Roseburg folio, Oregon: U.S. Geol. Survey, Geol. Atlas of U.S., Folio no. 49. 
1902, Topographic development of the Klamath Mountains: U.S. Geol. Survey Bull. 196. 1907, Mesozoic sediments of southwest Oregon: Am. Jour. Sci., 4th ser., v. 23, no. 138, p. 401-421.

Diller, J. S., and Kay, G. F., 1924, Description of the Riddle quadrangle, Oregon: U.S. Geol. Survey, Geol. Atlas of U.S., Folio no. 218 .

Dole, H., Geologic map of Dutchman Butte quadrangle: oregon Dept. Geol. and Mineral Indus., unpub.

Dott, R. H., 1971, Geology of the southwestern Oregon coast west of the 124 th Meridian: Oregon Dept. Geol. and Mineral Indus. Bull. 69, 63 p.

Hamilton, W., 1969, Mesozoic California and the underflow of Pacific mantle: Geol. Soc. America Bull., v. 80, no. 12, p. 2409-2430.

Harms, J. E., 1957, Geology of the southeast one-quarter of the Camas Valley quadrangle, Douglas County, Oregon: Oregon State College masters thesis, unpub.

Imlay, R. W., Dole, H. M., Wells, F. G., and Peck, D. L., 1959, Relations of certain Upper Jurassic and Lower Cretaceous formations in southwestern Oregon: Am. Assoc. Petroleum Geologists Bull., v. 43, no. 12, p. 2720-2785.

Johannesen, N. P., 1972, The geology of the northeastern quarter of the Bone Mountain quadrangle, Oregon: Univ. Oregon masters thesis, unpub.

Jones, D. L., and Irwin, W. P., 1971, Structural implications of an offset early Cretaceous shoreline in northern California: Geol. Soc. Amer. Bull., v. 82, p. 815-822.

Kent, R. C., 1972, The geology of the southeast quarter of the Bone Mountain quadrangle, Oregon: Portland State Univ. masters thesis, unpub.

Koch, J. G., 1966, Late Mesozoic stratigraphy and tectonic history, Port Orford, Gold Beach area, southwestern Oregon coast: Am. Assoc. Petroleum Geologists Bull., v. 50, no. 1 , p. 25-71. 
Perttu, R. K., and Benson, G. T., 1975, Eocene sedimentation and structural development of the Sutherlin area, southwestern Oregon, Oregon Academy of Science Abstracts.

(in prep.), The Canyonville fault zone and its effect on the geologic development of southwestern Oregon.

Peterson, N. V., 1957, The geology of the southeastern third of the Camas valley quadrangle, Oregon: Univ. Oregon masters thesis, unpub.

Ramp, L., 1972, Geology and mineral resources of Douglas County, Oregon: Oregon Dept. of Geol. and Mineral Indus. Bull. 75.

Wells, F. G., and Peck, D. C., 1961, Geologic map of Oregon west of the l2lst Meridian: U.S. Geol. Survey Misc. Geol. Inv. Map I-325, in coop. with Oregon Dept. of Geol. and Mineral Indus. 